\title{
Öğretmen Adaylarının Öğretim Becerilerini Geliştirmede Akran Koçluğunun Rolü
}

\section{Serpil Özdemir ${ }^{1}$}

$\ddot{O} \mathrm{z}$

$\mathrm{Bu}$ çalışmanın amacı akran koçluğunun öğretmenlik becerilerinin gelişimine etkisini belirlemektir. Araștırma karma yöntemlerden açıklayıcı sıralı desenle yürütülmüștür. Araștırmaya Bartın Üniversitesi Eğitim Fakültesi Türkçe Öğretmenliği Lisans Programından 50 öğrenci katılmıştır. Nicel veriler Mikro Öğretimi Değerlendirme Formuyla, nitel veriler yarı yapılandırılmış görüşme formu ile toplanmıştır. Verilere $t$ testi ve içerik analizi uygulanmıştır. Araştırma sonucunda plan yapma, derse giriş, dersi geliştirme ve genel başarı boyutlarında deney grubu lehine; konu alan bilgisi ve iletişim boyutlarında kontrol grubu lehine anlamlı farklar belirlenmiș, dersi kapatma boyutunda anlamlı bir fark görülmemiştir. Katılımcılar mesleki gelişim, görüş ve deneyim paylaşımı ve duyuşsal gelişim açısından akran koçluğunun olumlu katkılar yaptığını düşünmektedirler. Danışanlar mikro ögretime kısa sürede hazırlanmaktan, önceden hatalarını görmekten, eğlenerek öğrenmekten ve koçlara her an soru sorabilmekten memnundurlar. Katılımcılar akran koçluğunun yaratıcı düşünmeyi engellemesinden endișelenmektedirler. Akran koçluğunun öğretim programında yer alması, danıșanların planlarını yaptıktan sonra koçlarla çalışmaya başlamaları, iki tarafin da her aşamada yaşadıklarını öğretim

Akran koçluğu Öğretmen eğitimi Öğretmenlik uygulamas Öğretim becerileri

Makale Hakkında

Gönderim Tarihi

15 Mayis 2021

Kabul Tarihi

07 Ekim 2021

Makale Türï

Araştırma Makalesi elemanına rapor etmesi önerilmektedir.

\section{The Role of Peer Coaching on Improving Pre-Service Teachers' Instructional Skills}

\section{Abstract}

This study aims to explore the effect of peer coaching on instructional skills. 50 students attending Bartın University, Turkish Teaching Undergraduate Program participated in this mixed-methods study with explanatory sequential design. Quantitative data were collected with the Micro Teaching Evaluation Form and qualitative data were collected with a semi-structured interview form. t-test and content analysis were used in the analysis. It was found that there were significant differences in favor of the experimental group in the dimensions of lesson planning, lesson-opening, development of the lesson and overall success while the data yielded significant differences in favor of the control group in the knowledge and communication dimensions. Yet, there was no significant difference in lessonclosure dimension. Participants stated that peer coaching contributed positively to professional development, sharing of opinions and experiences, and affective development. Coachees were found to be enjoying microteaching, spotting their mistakes in advance, learning by having fun and asking questions to the coaches at any time. Participants were concerned that peer coaching interfered with creative thinking. Integrating peer coaching in the curriculum, encouraging peer coaching after preparation of lesson plans, and collecting reports from the students at each stage are among the educational implications recommended.
Keywords

Peer coaching Teacher education Teaching practicum Instructional skills

Article Info

Received

May 15, 2021

Accepted

October 07, 2021

Article Type

Research Paper

Attf: Özdemir, S. (2021). Öğretmen adaylarının öğretim becerilerini geliştirmede akran koçluğunun rolü. Ege Eğitim Dergisi, 22(2), 112-131. doi: 10.12984 /egeefd.937681

1 D Bartın Üniversitesi, Eğitim Fakültesi, Türkçe ve Sosyal Bilimler Eğitimi Bölümü, Türkiye, serpilozdemir34@gmail.com 


\section{Extended Abstract \\ Introduction}

Teaching skills include planning, dominance of the subject area, integrating technology and materials with the acquisition, using teaching methods and techniques appropriate for the outcome, evaluating the outcome and ensuring classroom management while doing these. Peer coaching is a learning strategy that facilitates the adaptation of teachers and teacher candidates to the profession, the development of teaching skills, and the application of newly acquired skills in the classroom (Vacilotto \& Cummings, 2007). In this method, teacher candidates exchange ideas with each other, observe each other and provide consultancy support to apply the teaching strategy and method correctly and to produce alternative solutions to instructional concerns (Karakaya Cirit, \& Aydemir, 2019).

When the studies conducted in Turkey are examined, it is seen that there are a limited number of studies examining the effect of peer coaching on pre-service teachers' preparation for the profession. Some studies are based on the quality of feedback (Karakaya Cirit, \& Aydemir, 2019; Kuru Gönen, 2016). Göker (2006) investigated the effect of peer coaching on the teaching competencies of prospective English teachers, others are qualitative studies aimed at determining the opinions of prospective teachers (Çapan \& Bedir, 2019; Göker, 2006; Kavanoz \& Yüksel, 2010; Kuru Gönen, 2016; Mirzeoğlu \& Özcan, 2015). No peer coaching work with Turkish teacher candidates has been found. The aim of this study is to determine which teaching skills develop more with the peer coaching method through an experimental study and the opinions of teacher candidates towards practice in a qualitative way. The research is unique with its sample and method, and it is predicted that it will contribute to the literature due to the limited number of experimental studies.

The problem sentence of the research is how is the effect of peer coaching on the development of teaching skills? The subject has been addressed with the following sub-problems:

1. What is the effect of peer coaching on subject matter knowledge, planning, lesson opening development of the lesson, lesson closure and communication with the student?

2. What are the preservice teachers' views on peer coaching?

\section{Method}

The research was carried out with explanatory sequential design, which is one of the mixed methods. Students from Bartın University Faculty of Education, Turkish Teaching Undergraduate Program participated in the study. The control group consisted of 20 third-year students who took the Special Teaching Methods I course and preferred to prepare themselves for micro teaching practice. 20 students who preferred to prepare with their peer coaches formed the experimental group. 10 fourth-year students participated in the research as a coach. The quantitative data of the study were collected by Micro Teaching Evaluation Form. The qualitative data of the study were collected using a semi-structured Peer Coaching Interview Form. Interviews were conducted with 9 students from the coaches and 10 students from the coachees. A total of 50 students participated in the study. $T$ test and content analysis were used in the analysis of the data.

\section{Findings}

The findings revealed that there were significant differences in favor of the experimental group in the dimensions of "planning, lesson opening development of the lesson, and general success", while there were significant differences in favor of the control group in the subject area knowledge and communication dimensions, yet there was no significant difference between the groups in the dimension of lesson closure Coaches and coachees think that peer coaching makes positive contributions in terms of professional development, sharing of opinions and experiences, and affective development. The coachees were pleased to be prepared for micro-teaching in a shorter time with their peer coaches, to have the chance to correct their mistakes before teaching, to learn with fun, and to be able to reach and ask questions to the coaches at any time. However, the problem of finding common time has been a problem for both sides. Participants in the research have concerns that receiving peer coaching support will prevent creative thinking.

\section{Discussion and Conclusion}

The fact that the experimental group is found to be more successful in planning, lesson opening the development and general success dimensions can be explained by the practice being beneficial in terms of preparation for teaching and professional development. Since the coachees rehearsed in front of an experienced person before the instruction, they had the opportunity to see and correct their mistakes and obtained information from their coaches on strategic points at every stage of the teaching. The coaches made sure that the coachees did not make any mistakes in front of the student, both at the planning stage and during the rehearsal before the presentation. These results are consistent with many studies showing that peer coaching improves teaching skills (Arslan Dönmez, 
2020; Göker, 2006; Kasapoğlu, 2002; Kavanoz \& Yüksel, 2010; Mirzeoğlu \& Özcan, 2015; Scott \& Miner, 2008; Vacilotto \& Cummings, 2007).

The difference in subject-area knowledge and communication dimensions in favor of the control group can be explained by the coaches' guidance to the coachees on teaching planning and teaching skills. In addition, the effect of peer coaching activities on subject matter knowledge can be seen as a result of repetitive studies in the process. Karakaya Cirit and Aydemir (2019) stated that there is a strong relationship between subject matter knowledge development and the time spent in the peer coaching process.

Coaches and coachees shared positive opinions on the themes of professional development, sharing of opinions and experiences, and affective development. Peer coaching has contributed to the professional development of both sides. The coachees acquired strategic information about every stage of teaching, they saw that they were effective in classroom management, and stated that what they learned would be permanent information. Coaches have seen that they have progressed professionally; they stated that their professional knowledge has increased, and they feel more ready for the profession. Both sides have gained confidence that they can do the teaching profession.

The fact that the coachees rehearsed their lessons before the teaching session with an experienced person enabled them to complete their teaching preparations in a shorter time and to have the opportunity to correct their mistakes. Reviewing various options for the best teaching practice by collaborative learning and brainstorming offered the opportunity to learn with fun. Especially, having open communication with their peers at all times, asking questions to the peers more comfortably created an opportunity for the coachees to solve the problems they encountered, and fostered friendships to form between two parties.

Common problems for both sides in peer coaching are related to timing and preventing creative thinking.

Recommendations developed for the effective use of peer coaching are as follows:

1. As a part of teacher candidates' preparations for the profession, peer coaching should be officially included in the curricula of education faculties (Britton \& Anderson, 2010; Çapan \& Bedir, 2019; Lu, 2010).

2. It is more appropriate for the coachees to start working with coaches after they have made their teaching plans to make sure they can make creative teaching designs.

3. In order for the coaches and coachees to fully adopt their roles in the process, it should be ensured that they receive a good training and even follow a few sample studies.

4. It may be functional for the peers to behave more consistently and in accordance with the expectations if both parties present a short report of their experiences at each stage during the studies.

5. Making lesson observations based on criteria has been determined as an element that supports critical thinking. For this reason, it is recommended that the observation criteria be determined in advance. 


\section{Giriş}

Sanayi toplumundan bilgi toplumuna doğru değişen yaşam, öğretmenlerin sürekli olarak yeni beceriler geliștirmelerini gerektirmektedir. Öğretim programları 21. yüzyıl becerileri doğrultusunda güncellenmiștir. Bu beceriler öğrenme ve yenilenme, bilgi teknolojileri, yaşama ve mesleğe uyum ana başlıkları altında ele alınmaktadır. Öğrenme ve yenilenme becerileri geliştirebilmek için günümüz insanlarının "yaratıcılık, eleştirel düşünme, problem çözme, iletişim ve iş birliği” becerilerini geliştirmesi gerekmektedir. Bilgi teknolojileri açısından "bilgi, medya ve iletişim" okuryazarı olmak kaçınılmaz hâle gelmiştir. Yaşama ve mesleğe uyum sağlamak için "esneklik, girişimcilik, öz-yönelim, sosyal beceriler, kültürlerarası beceriler, üretkenlik, liderlik" becerileri gelişmiş bireyler yetiştirmek amaçlanmaktadır (Bal, 2018). Öğretim programlarının bu amaçlara ulaşabilmesi için öğretmenlerin ve öğretmen adaylarının da 21. yüzyıl becerilerinin gelişmiş olması önemlidir.

Günümüzde öğretmen adaylarının, alan bilgisine sahip olmaları yeterli görülmemektedir. Bu bilgiyi teknolojik ve pedagojik bilgiyle birleştirmeleri, öğrenmek, gelişmek ve mesleğe uyum sağlayabilmek için çok yönlü beceriler geliştirmeleri beklenmektedir. Öğretim, planlamayla başlayan bir süreçtir. Öğretim becerileri de planlama, konu alanı hâkimiyeti, teknolojiyi ve materyalleri kazanımla bütünleştirme, kazanıma uygun öğretim yöntem ve tekniklerini kullanabilme, kazanımı değerlendirebilme ve bunları yaparken sınıfı etkili yönetebilme gibi pek çok beceriyi kapsamaktadır. Öğretim becerileri gelişmiş bir öğretmen sınıfta neyin, nasıl işlediğinin farkında olan ve sınıfta işleyen bu faktörleri kontrol altında tutup işletebilen kişidir (Bayındır, Çavdar ve Gökçe, 2016). Bu çerçevede eğitim fakülteleri, alan bilgisini teknolojik pedagojik bilgiyle birleștiren ve bu bilgileri öğretim sürecinde amaca uygun şekilde kullanabilen öğretmen adayları yetiştirme gayretindedir.

Öğretmen adaylarının çok yönlü gelişimlerini sağlayabilmek, yeni öğretim yöntemleri gerektirmektedir. Günümüzde yeni yöntem arayışları devam etmekle birlikte mikro öğretim yöntemi öne çıkmaktadır. Mikro öğretim uygulamaları alan bilgisini pedagojik bilgiyle birleştirmede ve öğretmen adaylarını mesleğe hazırlamada en sık kullanılan yöntemlerden biridir. Ancak dersliklerin kalabalık olması ve Yüksek Öğretim Kurulunun uygulamalı dersleri kaldırması gibi nedenlerle öğretmen adaylarının pek az uygulama fırsatı olmaktadır. Uygulamalar incelendiğinde öğretmen adaylarının plan hazırlama, hazırlanan planı uygulama, derse giriş yapma; dersi geliştirirken uygun stratejiler kullanma, yönlendirmeler yapma, soru sorma, dönüt verme; dersi kapatırken özetleme ve değerlendirme ile ilgili sorunlar yaşadıkları görülmektedir (Özdemir, 2019). Gerek mikro öğretim uygulamalarında gerekse öğretmenlik uygulamalarında öğretmen adayı gözlem, inceleme, planlama, uygulama gibi süreçleri bireysel olarak yürütmektedir (Müldür ve Çevik, 2020). Öğretmen adaylarının daha iyi mikro öğretim performansı gösterebilmeleri, okul deneyimi sürecine daha kolay uyum sağlayabilmeleri için bireysel çalışmalar yerine iş birlikli çalışmalar yapılması, onlara ihtiyaç duydukları desteği sağlayabilir. Bu çerçevede akran koçluğu, ders imecesi, öğretimi öğrenme ekibi gibi yöntemlere giderek daha fazla ihtiyaç duyulmaktadır.

Koçluk, uygulanacak eğitim materyali üzerine bir uzman tarafından tartışmalar yapılırsa ve performans hakkında geri bildirim sağlanırsa performansın geliştirilebileceği anlayışına dayanmaktadır (Lockwood, McCombs ve Marsh, 2010). Akran koçluğu öğretmenlerin ve öğretmen adaylarının mesleğe uyumunu, öğretim becerilerinin geliştirilmesini ve yeni edinilen becerilerin sınıfta uygulanmasını kolaylaştıran (Vacilotto ve Cummings, 2007) bir öğrenme yöntemidir. $\mathrm{Bu}$ yöntemde öğretmen adayları fikir alışverişinde bulunur, birbirlerini gözlemler, doğru öğretim strateji ve yöntemini uygulamaya ve öğretimsel kaygılara alternatif çözümler üretmeye çalışırlar (Karakaya Cirit ve Aydemir, 2019). Bu iş birliğinin sonucunda bireyler kendi bakış açılarını geliştirip güçlü yönlerini ortaya çıkarabilmektedirler (Bowman ve McCormick, 2000). Dolayısıyla koçluk, öğretmen adaylarının planlanma aşamasında farklı bakış açıları ile karşılaşmalarını, uygulamaya yönelik güçlü yönlerini görmelerini ve zayıf yönlerini geliştirmelerini sağlayabilecek bir iş birlikli öğrenme sürecidir.

Akran koçluğu çalışmalarında gruplar genellikle iki kişiden oluşmaktadır ancak farklı eşleştirmeler yapılabilmektedir. Aynı sınıf içindeki öğrenciler eşleştirilebildiği gibi yaşça büyük ya da daha tecrübeli öğrenciler, kendilerinden küçük ya da tecrübesiz öğrencilerle eşleştirilebilmektedir. Öğrencilerden biri öğrenen diğeri öğretici rolünde çalışmaya katılmaktadır. Öğrenen ve öğretici rolleri değiştirilebildiği gibi roller sabit de kalabilmektedir. Akran koçluğu sürecinin etkili bir şekilde ilerlemesi için öğretici rolündeki akranların istekliliği, akranı ile iletişimi, öğretme stratejilerini kullanma becerisi, uygun dönütler vermesi, akranının uygun kaynaklara ulaşmasını sağlaması, akranına etkili sorular yöneltmesi gibi özellikleri taşıması gerekmektedir (Goldschmid ve Goldschmid, 1976, akt. Koç, 2020). Koçlar danışanların ödev ve sorumluluklarını onların yerine yapmakla görevli değillerdir. Koçlardan beklenen danışan öğrencinin hangi noktalarda sorun yaşadığını belirlemek, çözüm önerilerinin neler olabileceğini birlikte gözden geçirmek, uzlaşma ile sorunu çözmeye çalışmaktır. Bu süreçten yararlanabilmek için danışan öğrencilerin de yardıma ihtiyaç duydukları konuları belirlemeleri ve etkili dinleme, açık fikirli olma, zorluklarla baş edebilme, etkin öğrenme niteliklerine sahip olmaları gerekmektedir (Starr, 2003). Bu süreç, danışana güçlü ve zayıf noktaları hakkında kendisini tanıması için bir firsat yaratırken koça da bilişsel farkındalık geliştirme olanağı sunmaktadır. Akran koçluğunun başlıca amacı öğretim yöntem ve tekniklerini etkili kullanmayı sağlamaktır. Ancak yapılan iş birliği sonucunda -çağımız insanından beklenen- eleştirel düşünme, problem çözme, iletişim ve iş birliği içinde çalışma becerilerinde gelişme de diğer çıktılar arasında sayılabilir (Hooker, 2013). 
Akran koçluğu, öğretmenlik becerileri ile birlikte bilgi toplumunun ihtiyaç duyduğu öğrenme ve yenilenme, yaşama ve mesleğe uyum sağlayabilme becerilerini de geliştirebilir.

Akran koçluğu üç aşamadan oluşmaktadır. İlk aşama, gözlem öncesi görüşmedir. Bu aşamada danışan ve koç dersi planlar; uygulanacak olan öğretim yaklaşımı, yapılabilecek etkinlikler, karşılaşılabilecek zorluklar veya endişe yaratan durumlar, gözlemlenecek noktalar ve gözlemin nasıl yapılacağı belirlenir. İkinci aşama gözlem aşamasıdır. $\mathrm{Bu}$ aşamada danışan tarafından öğrencilerle birlikte ders işlenir ve koç tarafından ders gözlemlenir. Gözlem sırasında öğretimin içeriği, tarzı ve sunumu hakkında dönüt verebilmek için notlar alınır. Gözlemin ölçütlere dayalı olarak yapılabilmesi için likert tipi bir ölçekten yararlanılabilir. Böylece gözlemde odaklanılacak noktalar her öğrenci için standart hâle getirilir. Son aşama, gözlem sonrası görüşmedir. Gözlenen ders yorumlanır, yapılan öğretimle ilgili geri bildirimler yapılır ve düşünceler paylaşılır. Geri bildirim izlenen derse özel, değiş̧irilebilecek davranışlara yönelik, gözlenen sorunların tamamını değil, seçilen temel sorunları kapsayan, danışanın kişiliğini değil, ders esnasındaki davranışlarını hedef alan bir tutumla yapılmalıdır (Alsaleh, Alabdulhadi ve Alrwaished, 2017; Sullivan, Buckle, Nicky ve Atkinson, 2012). Akran koçluğunu mikro öğretimden ayıran yanı, gözlem öncesi görüşmedir. Gözlem ve gözlem sonrası görüşme aşamaları mikro öğretimle ortaktır. Akran koçluğunda gözlem öncesi başlayan görüşmeler öğretmen adaylarının dersi planlamalarını, endişe ve kaygı gibi psikolojik etkenlerle daha kolay başa çıkmalarını sağlamaktadır.

Öğretmen adaylarıyla ve öğretmenlerle yapılan çalışmalar akran koçluğunun; öğretim becerilerini (Arslan Dönmez, 2020; Göker, 2006; Kasapoğlu, 2002; Kavanoz ve Yüksel, 2010; Mirzeoğlu ve Özcan, 2015; Scott ve Miner, 2008; Vacilotto ve Cummings, 2007), sınıf yönetimi becerilerini (Arslan Dönmez, 2020; Yalçın Arslan ve İlin, 2013), meslektaşlar arası ilişkileri (Arslan Dönmez, 2020; Bowman ve McCormick, 2000), mesleki özgüveni (Alsaleh ve diğ,, 2017; Çapan ve Bedir, 2019; Göker, 2006; Kurtts ve Levin, 2000; Vacilotto ve Cummings, 2007) geliştirmede etkili olduğunu göstermektedir. Pierce ve Miller (1994) ise akran koçluğu çalışmasının öğretim davranışlarında fark göstermediğini belirlemişlerdir. Bazı araştırmalar akran koçluğu uygulamasının dönüt verme aşamasına odaklanmıştır. $\mathrm{Bu}$ aşamada öğretmen adayının nereyi öğrenmekte zorlandığı, öğretimde hangi teknolojik araç-gereçlerin, değerlendirmede hangi yolun daha etkili olduğu vb. birçok bilgi alanı açısından yansıtma görebilmektedir. Bu araştırmalar da akran koçluğunun teknolojik pedagojik alan bilgisi açısından öğretmen adaylarını geliştirdiğini göstermektedir (Anderson, Barksdale ve Hite, 2005; Huston ve Weaver, 2008; Karakaya Cirit ve Aydemir, 2019; Kuru Gönen, 2016; Lu, 2010).

Akran koçluğu öğretmen yetiştirme açısından oldukça etkili görünmektedir. Ancak her yöntemin kendi içinde sinırlılıkları ya da sorunlu yanları olabilmektedir. Aynı sınıftaki akranların aynı deneyim ve bilgiye sahip olmalarından dolayı birbirlerine desteği sınırlı olabilir (Lu, 2010). Akran koçları profesyonel öğretmenler olmadıkları için, akranlarını nasıl destekleyeceklerini bilemeyebilirler. Koçların etkili bir destek verebilmeleri için gözlem öncesinde eğitim almaları önemlidir. Bu eğitimde hangi öğretim becerilerine odaklanacakları, yönlendirici olmayan soruları nasıl sorabilecekleri, gözlenen dersi nasıl analiz edebilecekleri, ölçütlere dayalı olarak nasıl geri bildirim verebilecekleri açıklanmalıdır (Ovens, 2004). Ladyshewsky (2017) başarılı bir akran koçluğunun beş temel adımı olduğunu belirtmektedir. Bunlar akran çiftlerini oluşturmak, eşler arasında güven oluşturmak, öğrenme hedeflerini belirlemek, yargılamayan sorular sormak ve geri bildirim vermek üzerine eğitim almak ve yeni fikirleri desteklemektir. Bu adımları eksiksiz yerine getirmek ve eşleşen öğrencileri düzenli olarak gözlemek öğretim elemanına fazladan iş yükü hâline gelebilir. Yetişkin ve deneyimli öğretmenlerden eğitim almayı tercih etmek, öğreten ve öğrenen arasında eşit bir ilişki kurulmaması (Demirel, 2013), öğreticiye çok fazla iş yükü oluşturması, görüşme zamanlarını planlamada uygun bir ortak bir zaman bulamama (Çapan ve Bedir, 2019; Kurtts ve Levin, 2000) akran öğretiminde görülebilecek sorunlar arasında sayılabilir.

Türkiye'de yapılan çalışmalar incelendiğinde akran koçluğunun öğretmen adaylarının mesleğe hazırlanmasına etkisini inceleyen sınırlı sayıda araştırma olduğu görülmektedir. Karakaya Cirit ve Aydemir (2019) ile Kuru Gönen (2016) tarafından yapılan çalışmalar dönüt niteliğine dayalıdır. Göker'in (2006) çalısması İngilizce öğretmeni adaylarının öğretim yeterliklerinde akran öğretiminin etkisini araştırmaya yönelikken diğerleri öğretmen adaylarının görüşlerini belirlemeye yönelik nitel araştırmalardır (Çapan ve Bedir, 2019; Göker, 2006; Kavanoz ve Yüksel, 2010; Kuru Gönen, 2016; Mirzeoğlu ve Özcan, 2015). Türkçe öğretmeni adaylarılla akran koçluğu çalışması yapılmamıştır. Bu araştırmada akran koçluğunun hangi öğretim becerilerini geliştirmede daha etkili olduğunu ve öğretmen adaylarının uygulamaya yönelik görüşlerini belirlemek amaçlanmaktadır. Araştırmanın örnekleminin ve yönteminin özgün olduğu ve deneysel çalışmaların sınırlı sayıda olması nedeniyle alanyazına katk1 sunabileceği düşünülmektedir.

Araştırmanın problem cümlesi “Akran koçluğunun öğretmenlik becerilerinin gelişimine etkisi nasıldır?" şeklinde belirlenmiştir. Konu şu alt problemlerle ele alınmıştır:

1. Akran koçluğunun konu alan bilgisine, planlamaya, derse giriş yapmaya, dersi geliştirmeye, dersi kapatmaya ve öğrenci ile iletişime etkisi nasıldır?

2. Öğretmen adaylarının akran koçluğuna ilişkin görüşleri nasıldır? 


\section{Yöntem}

\section{Araştırmanın Deseni}

Araştırma karma yöntemlerden açıklayıcı sıralı desenle yürütülmüştür. Bu desende amaç, nicel yöntemle toplanan verilerin içindeki ilişkileri ve yönelimleri nitel verilerle açıklamaktır (Creswell ve Plano Clark, 2015). Araştırmanın nicel boyutunda zayıf deneysel desenlerden eşitlenmemiş gruplar son-test deseni uygulanmıştır. Bu desende yalnızca deney sonunda ölçmeler yapılarak deney ve kontrol grupları bağımlı değişken açısından karşılaştırılmaktadır (Johnson ve Christensen, 2014). Araştırma öncesinde öğrencilerin planlama ve uygulama yapma açısından özellikleri bilinmediğinden ve katılımcıların tümüne mikro öğretim yaptırılarak bu özelliklerinin belirlenmesi zaman açısından ekonomik olmadığından eşitlenmemiş grup son-test modeli kullanılmıştır. Araştırmada mikro öğretim uygulamalarına akran koçlarıyla hazırlanan 20 öğretmen adayı deney grubunu, kendi kendine hazırlanan 20 öğretmen adayı ise kontrol grubunu oluşturmuştur. İki grubun mikro öğretim başarı puanları, araştırmanın nicel verilerini oluşturmuştur.

Araştırmanın nicel verilerini açıklamak amacıyla katılımcıların konuya yönelik bakış açıları, deneyimleri ve algıları, nitel araştırma yöntemlerinden yarı yapılandırılmış görüşme yöntemiyle belirlenmeye çalışılmıştır. Bu sayede akran koçluğu uygulamalarına katılanların uygulamaya yönelik deneyim ve görüşlerinin nasıl olduğu belirlenmeye çalışılmıştır. Danışanların ve koçların görüşleri ayrıca analiz edilmiştir.

\section{Çalışma Grubu}

Araştırma 2019-2020 eğitim öğretim yılında, Bartın Üniversitesi Türkçe Öğretmenliği Lisans Programında okuyan öğrenciler ile yürütülmüştür. Araştırmanın nitel ve nicel verileri toplam 50 öğrenciden toplanmıştır. Araştırmanın deneysel kısmı 3. sınıfta yer alan Özel Öğretim Yöntemleri I dersinde yürütülmüştür. Bu ders, mikro öğretim uygulaması yapmaya uygun olduğu için seçilmiştir. Türkçe Öğretmenliği Lisans Programındaki derslerde mikro öğretim uygulamaları 3. sınıfta başlamaktadır. Koçların deneyimli öğrencilerden olması planlandığı için 4. sınıf öğrencileri koç olarak görev yapmışlardır. Araştırmacının Özel Öğretim Yöntemleri I dersini vermesi nedeniyle kolay ulaşılabilir örnekleme yöntemi tercih edilmiştir. Kolay ulaşılabilir örnekleme yönteminde yakın olan ve erişilmesi kolay olan bir durum seçilmektedir (Yıldırım ve Şimşek, 2013). Araştırmacının aynı fakültede derslerine girdiği 4. sınıftan 10 öğrenci, 3. sınıftan deney ve kontrol gruplarında yer alan 20'şer öğrenci, araştırmanın çalışma grubunu oluşturmuştur.

Nitel boyutta amaçlı örnekleme yöntemlerinden ölçüt örnekleme yöntemi kullanılmıştır. Ölçüt örneklemede önceden belirlenen bir dizi ölçütü karşılayan durumlarla çalışma yürütülmektedir (Yıldırım ve Şimşek, 2013). Nitel veriler araştırmanın nicel verilerini yorumlamak amacıyla toplanacağ için nicel araştırma sonucunda deney grubunda mikro öğretim başarısı ortalama altında ve ortalama üstünde olan danışanların görüşlerinin katk1 sunabileceği değerlendirilerek örneklem oluşturma ölçütü olarak nitelendirilmiştir. Deney grubunun mikro öğretim başarı ortalamasının 87.12 olduğu belirlenmiştir. 6 öğrencinin ortalamanın altında, 14 öğrencinin ortalamanın üstünde puan aldıkları belirlenmiştir. Belirlenen öğrencilerle bireysel görüşme yapılmıştır. Araştırmada sınırlı sayıda koç görev aldığı için koçlardan örneklem alınmamıştır. Görüş bildirmeyi kabul eden ortalama altında ve üstünde beşer öğrenci ve 9 koç ile görüşme yapıldıktan sonra verilerin yeterli derinliğe ve çeşitliliğe ulaştığı görülüp veri toplama süreci durdurulmuştur.

\section{Veri Toplama Araçları}

Araştırmanın nicel verileri Mikro Öğretimi Değerlendirme Formu ile toplanmıştır. Mikro Öğretimi Değerlendirme Formu, araştırmacı tarafından literatür taraması ve uzman görüşü alınarak oluşturulmuştur. Oluşturulan 36 maddelik form, 2018-2019 eğitim öğretim yılı güz döneminde Özel Öğretim Yöntemleri I dersinde yapılan mikro öğretim uygulamalarında kullanılmıştır. Yapılan uygulamalar sonucunda formun öğretmen adayları tarafindan kullanışlı bulunmadığı belirlenmiştir. Akran değerlendirmesi yapan öğretmen adayları, formun daha az maddeden oluşmasının gözlemi kolaylaştıracağını belirtmişlerdir. Bunun üzerine öğretmen adayları ile görüş alışverişi yapılarak formda sadeleştirmeler yapılmıştır. Sadeleştirilen form 20 maddeden ve "plan, giriş, dersi geliştirme, kapanış, konu alan bilgisi ve iletişim” boyutlarından oluşmaktadır. Sadeleştirilmiş form, 2018-2019 eğitim öğretim yılı bahar döneminde Özel Öğretim Yöntemleri II dersinde yapılan mikro öğretim uygulamalarında kullanılmış ve öğretmen adayları tarafindan kullanışlı bulunmuştur. İki öğretmen adayı ve iki uzman tarafindan 10 öğrencinin uygulaması, bu form ile değerlendirilmiştir. Yapılan değerlendirmelerin güvenilir olup olmadığını belirlemek üzere değerlendiriciler arası uyuma bakılmıştır. Bütün boyutlarda ve genel toplamda değerlendiriciler arası Kendall's $W$ uyum katsayısı hesaplanmıştır. Kendall's $W$ uyum katsayısı plan .94, giriş .88, dersi geliştirme .82 , kapatma .92, konu alan bilgisi .91 , iletişim boyutunda .85 ve genel toplamda .88 olarak belirlenmiştir. Değerlendiriciler arasında istatistiksel olarak anlamlı derecede uyum $(p<0.01)$ bulunması, mikro öğretimi değerlendirme formunun güvenilir olduğunun göstergesi olarak kabul edilmiştir.

Araştırmanın nitel verileri yarı yapılandırılmış Akran Koçluğuna Yönelik Görüşme Formu ile toplanmıştır. Görüşme formu araştırmacı tarafından literatür taramasına ve araştırmanın amacına dayalı olarak hazırlanmıştır. 
Kapsam geçerliğini sağlamak üzere iki uzmandan görüş alınmış, gelen görüşler doğrultusunda formun adı ve soruların ifadesi koçlara ve danışanlara uygun şekilde düzenlenmiştir. Danışanlara hazırlanan form "Akranla Öğrenmeye Yönelik Görüşme Formu”, koçlara hazırlanan form “Akran Öğretimi Yapmaya Yönelik Görüşme Formu" adıyla düzenlenmiştir. Danışanlara "Mikro öğretim uygulamasına öğretmen adayı ile hazırlanmaktan memnun musunuz? Nedenleri nelerdir?", "Akranla çalışmanın hangi noktalarda yararlı olduğunu düşünüyorsunuz?”, “Akranla çalışmanın sizin için yararlı olmayan/zararlı olan yanları nelerdir?”, "Daha sonra yapılacak akran öğretimi çalışmaları için neler önerisiniz?” soruları sorulmuştur. Danışanların soruları daha derin cevaplaması için sorunun özelliğine bağlı olarak sondalar da eklenmiştir. Sondalar, toplanan verinin derinlemesine olmasını ve zenginleşmesini sağlayan önemli etkenlerdir (Yıldırım ve Şimşek, 2013). 1. soruya öğretmen adayının kişiliği, sizinle olan iletişimi, alan bilgisi/deneyimi ve diğer soruları sonda olarak eklenmiştir. 2. soruya plan yazma, derse giriş yapma (dikkat çekme, güdüleme, konuyu sezdirme, amaç belirleme vb.), dersi geliştirme, etkinlik tasarlama, dersi kapatırken uygun bir değerlendirme yapabilme, kazanıma uygun ödev belirleme, duygusal olarak (kendine güven, hazır olmaktan dolayı rahatlık duymak vb.), sınıf yönetimi ve diğer soruları sonda olarak eklenmiştir. Koçlara “Akran öğretimi yapmanın sizin için olumlu yönleri nelerdir?”, “Akran öğretimi yapmanın olumsuz/zor/sıkıcı vb. yanları nelerdir?", "Etkili bir akran öğretimi için tavsiyeleriniz nelerdir?" soruları sorulmuştur.

\section{Veri Toplama Süreci}

Araştırmanın deneysel süreci grupların mikro öğretim tekniğine, dersi planlamaya ve uygulamaya yönelik hazırlık aşaması ve akran koçluğunun gözlem öncesi görüşme, gözlem ve gözlem sonrası görüşme aşamaları içinde yürütülmüştür.

Hazırlık Aşaması. Uygulama öncesinde 3. sınıf öğrencilerine mikro öğretim tekniği tanıtılmıştır. Ayrıca dersi planlama, Türkçe dersi öğretim yöntem ve teknikleri, süreç ve sonuç değerlendirme hakkında bilgilendirilmişlerdir. Son olarak akran koçluğu tanıtılmış ve yapılması planlanan araştırma hakkında bilgi verilmiştir. Öğrencilerden uygulamalara akran koçuyla hazırlanmak isteyenler belirlenmiştir. Bu süreç 8 ders saati sürmüştür.

Araştırmaya katılmaya gönüllü öğrencilere süreçteki rolleri, akran koçluğunun aşamaları hakkında bilgilendirme yapılmıştır. Bilgilendirme 2 saat sürmüştür.

4. sınıf öğrencilerine de araştırma hakkında bilgi verilmiştir. Alt sınıftaki öğrencilerle bilgi ve deneyimlerini paylaşmak isteyen öğrenciler belirlenmiştir. Gönüllü öğrencilerle uygulama öncesi toplantı yapılarak akran koçluğu ve mikro öğretim uygulamalarında öğrenciden beklenen planlama ve uygulama becerileri hakkında bilgilendirme yapılmıştır. Bilgilendirme sürecinde öğretim tekniklerini geliştirmede planlamanın önemi, bir dersin nasıl yapılandırılacağı, geliştirilecek ve gözlenecek becerilerin neler olabileceği konuları üzerinde durulmuştur. Mikro öğretim uygulamalarının gözleneceği değerlendirme formu tanıtılmıştır. Akran koçluğu sürecinde koçların rolü, etkili dinleme, etkili sorular sorma ve eleştirel dönüt verme konularında bilgi verilmiştir. Bilgilendirme 2 saat sürmüştür.

3. ve 4. sınıf öğrencilerinin ilk görüşme için bir araya gelmeleri sağlanmıştır. Öğrenciler kiminle çalışacaklarını bu görüşme esnasında kendileri belirlemişlerdir.

Gözlem Öncesi Görüş̧me Aşaması. Danışanlar ve koçlar, ders gözlemi öncesinde iki kez bir araya gelmişlerdir. İlkinde mikro öğretim uygulamasına başlamadan önce kazanıma uygun şekilde dersi planlama, öğretim yöntem ve tekniklerini belirleme, etkinlikleri tasarlama çalışmaları yapmışlardır. İkinci gözlemde ders tasarımını tamamlayan danışanlar, öğrencilerle birlikte uygulama yapmadan önce koçlara sunum yapmışlardır.

Gözlem Aşaması. Asıl uygulama Özel Öğretim Yöntemleri I dersinde yapılmıştır. Bu uygulamaya öğretici rolündeki koçlar izleyici olarak katılmıştır. Koçlar, mikro öğretimi değerlendirme formunda yer alan ölçütler çerçevesinde gözlem yaparak ders işleniş sürecine yönelik notlar almışlardır.

Gözlem Sonrası Görüşme. Mikro öğretim uygulamasından sonra danışanlar ve koçlar gözlemlerin değerlendirildiği bir görüşme yapmışlardır.

Araştırmanın tanıtılması, danışanlarla koçların eşleşmesi, uygulama öncesi hazırlıkların yapılması, dersin izlenmesi ve değerlendirmelerin yapılması, danışan rolündeki her bir öğrenci için 6 haftalık bir süreçte gerçekleşmiştir. Araştırma bulgularının tamamına ulaşmak için bütün öğrencilerin mikro öğretim uygulamalarını tamamlaması 8 hafta sürmüştür. Deney ve kontrol gruplarının dersleri aynı öğretim elemanı tarafindan yürütülmüştür.

Araştırmanın nicel verileri toplandıktan sonra akran koçluğu çalışmasında görev alan danışan ve koçlarla birebir görüşmeler yapılarak nitel veriler toplanmıştır. Görüşmeler her bir öğrenci için 10-15 dakika sürmüştür. Danışan rolündeki 3. sınıf öğrencilerinden ve koç rolündeki 4. sınıf öğrencilerinden görüş alınmıştır. 


\section{Veri Analizi}

Nicel verilerin analizi sürecinde, öncelikle akran koçluğunun konu alan bilgisine, planlamaya, derse giriş yapmaya, dersi geliştirmeye, dersi kapatmaya ve öğrenci ile iletişime etkisinin nasıl olduğunu belirlemeye yönelik olan birinci alt problemi için verilerin normal dağılım gösterip göstermediği incelenmiştir. Deney ve kontrol gruplarının büyüklükleri 50'den küçük olduğu için Shapiro-Wilks normallik testi yapılmıştır. Bu testte $p$ değerinin .05'ten büyük çıkması dağılımın normal olduğunun göstergesi kabul edilmektedir (Büyüköztürk, 2011). Bütün boyutlarda $p$ değeri .05'ten küçük çıkmıştır. Ayrıca çarpıklık katsayıları incelenmiştir. Normal dağılımda çarpıklık katsayısı +1 ile -1 arasında ise puanların olması beklenir (Büyüköztürk, 2011). Bütün boyutlarda çarpıklık katsayılarının normal aralıkta olmadığı belirlenmiştir. $\mathrm{Bu}$ belirlemeler verilerin normal dağılım göstermediği şeklinde yorumlanmıştır. Parametrik test varsayımları karşılanmadığı için parametrik olmayan testlerden Mann-Whitney $U$ testi ile analiz edilmiştir.

Öğretmen adaylarının akran koçluğuna ilişkin görüşleri nitel veri analizi yöntemlerinden içerik analizi yöntemiyle incelenmiştir. İçerik analizi, toplanan verileri açıklayan kavramları ve ilişkileri belirlemek amacıyla yapılmaktadır. Veriler derin bir incelemeden geçirilerek anlamlı bölümleri tanımlayan kodlara ulaşılır ve kodlar aralarındaki ortak özelliklere göre belirli kategoriler altında toplanarak adlandırılır. Böylece temalara ulaşılmış olur (Yıldırım ve Şimşek, 2013). Belirlenen temalar tablolar hâlinde sunulmuş ve alıntılarla desteklenmiştir. Alıntılarda koçlar için $\mathrm{K}$, danışanlar için D kodu kullanılmıştır ve sırayla numara verilmiştir. Örneğin K1 koç rolünde görüş bildiren birinci öğrenciyi, D1 danışan rolünde görüş bildiren birinci öğrenciyi işaret etmektedir.

\section{Geçerlik ve Güvenirlik Önlemleri}

Araştırmanın nicel verilerini oluşturan mikro öğretim değerlendirmelerinde güvenirliğini sağlamak için deney ve kontrol gruplarından rastgele seçilen sekizer öğrencinin mikro öğretim uygulamaları, üç uzman tarafindan izlenmiş ve değerlendirilmiştir. Değerlendiriciler arası Kendall's $W$ uyum katsayıları plan .96, giriş .90, dersi geliştirme .86, kapatma .94 , konu alan bilgisi .97 , iletişim boyutunda .88 ve genel toplamda .92 olarak belirlenmiştir.

Nitel veri seti kodlamaları iki uzman tarafından yapılmıştır. İki uzman tarafından yapılan kodlamanın iç tutarlılığı Miles ve Huberman'ın güvenirlik katsayısı formülü ile hesaplanmıştır. Bu formüle göre güvenirlik katsayısı "uzlaşılan kod sayısı / uzlaşılan kod sayısı + uzlaşılmayan kod sayısı"na eşittir. Kodlayıcılar arasında görüş birliğinin en az \% 80 olması beklenmektedir (Miles ve Huberman, 2019). Yapılan hesaplama sonucunda görüş birliğinin \% 87 olduğu belirlenmiştir. Bu sonuç, yapılan kodlamanın güvenilir olduğunu göstermektedir. Ancak uzmanlar arasında görülen farklı kodlar üzerinde tartışılarak uzlaşma yoluna gidilebilmektedir (Sağlam ve Kanadlı, 2021). İlk kodlamada uzlaşılmayan kodlar uzmanlar arasında tartışılmış ve görüş birliği sağlanmıştır.

\section{Etik Konular}

Araştırma için etik kurul izni alınmıştır. Katılımcılar araştırma ile ilgili bilgilendirilmiş, gönüllü katılımcılardan veri toplanmış ve onam formu aracılığıyla çalışmaya katılım izinleri alınmıştır.

\section{Nicel Bulgular}

\section{Bulgular}

Akran koçluğunun konu alan bilgisine, planlamaya, derse giriş yapmaya, dersi geliştirmeye, dersi kapatmaya ve öğrenci ile iletişime etkisinin nasıl olduğunu belirlemeye yönelik olan birinci alt problem için yapılan MannWhitney $U$ testinin sonuçları Tablo 1'de görülmektedir. 
Tablo 1

Akran Koçluğunun Konu Alan Bilgisine, Planlamaya, Derse Giriş Yapmaya, Dersi Geliştirmeye, Dersi Kapatmaya ve Öğrenci ile İletişime Etkisi

\begin{tabular}{|c|c|c|c|c|c|c|}
\hline Değerlendirme Formunun Boyutlar1 & Grup & $\mathrm{N}$ & Sira Ortalamas1 & Sira Toplamı & $U$ & $p$ \\
\hline Konu Alan Bilgisi & $\begin{array}{l}\text { Deney } \\
\text { Kontrol }\end{array}$ & $\begin{array}{l}20 \\
20\end{array}$ & $\begin{array}{l}18.00 \\
23.00\end{array}$ & $\begin{array}{l}360.00 \\
460.00\end{array}$ & 150 & .040 \\
\hline Plan & $\begin{array}{l}\text { Deney } \\
\text { Kontrol }\end{array}$ & $\begin{array}{l}20 \\
20\end{array}$ & $\begin{array}{l}27.58 \\
13.43\end{array}$ & $\begin{array}{l}551.50 \\
268.50\end{array}$ & 58.5 & .000 \\
\hline Giriş & $\begin{array}{l}\text { Deney } \\
\text { Kontrol }\end{array}$ & $\begin{array}{l}20 \\
20\end{array}$ & $\begin{array}{l}25.50 \\
15.50\end{array}$ & $\begin{array}{l}510.00 \\
310.00\end{array}$ & 100.0 & .000 \\
\hline Geliştirme & $\begin{array}{l}\text { Deney } \\
\text { Kontrol }\end{array}$ & $\begin{array}{l}20 \\
20\end{array}$ & $\begin{array}{l}24.18 \\
16.83\end{array}$ & $\begin{array}{l}483.50 \\
336.50\end{array}$ & 126.5 & .045 \\
\hline Kapatma & $\begin{array}{l}\text { Deney } \\
\text { Kontrol }\end{array}$ & $\begin{array}{l}20 \\
20\end{array}$ & $\begin{array}{l}18.63 \\
22.38\end{array}$ & $\begin{array}{l}372.50 \\
447.50\end{array}$ & 162.5 & .218 \\
\hline İletişim & $\begin{array}{l}\text { Deney } \\
\text { Kontrol }\end{array}$ & $\begin{array}{l}20 \\
20\end{array}$ & $\begin{array}{l}16.58 \\
24.43\end{array}$ & $\begin{array}{l}331.50 \\
488.50\end{array}$ & 121.5 & .026 \\
\hline Genel Başarı & $\begin{array}{l}\text { Deney } \\
\text { Kontrol }\end{array}$ & $\begin{array}{l}20 \\
20\end{array}$ & $\begin{array}{l}24.48 \\
16.53\end{array}$ & $\begin{array}{l}489.50 \\
330.50\end{array}$ & 120.5 & .030 \\
\hline
\end{tabular}

Yapılan analiz sonucunda akran koçluğu desteği alan deney grubu öğrencileri ile akran desteği almayan kontrol grubu ögrencilerinin arasında; konu alan bilgisi $(U=150, p<.05)$, planlama $(U=58.5, p<.05)$, derse giriş yapma $(U=100, p<.05)$, dersi geliştirme $(U=126.5, p<.05)$, iletişim $(U=121.5, p<05)$ ve genel başarı $(U=120.5$, $p<.05)$ bakımından anlamlı farklar olduğu, dersi kapatma açısından gruplar arasında anlamlı bir fark olmadığı belirlenmiştir. Sıra ortalamaları dikkate alındığında "konu alan bilgisi ve iletişim” boyutlarında fark, kontrol grubu lehinedir. "Plan yapma ve planı uygulama, derse giriş yapma, dersi geliştirme ve genel başarı" sıra ortalamaları, deney grubu lehine anlamlı farklar olduğunu göstermektedir.

\section{Nitel Bulgular}

Öğretmen adaylarının akran koçluğuna ilişkin görüşlerinin nasıl olduğunu belirlemeye yönelik olan ikinci alt problem akran koçları ve danışanlar açısından analiz edilmiştir. Yapılan analiz sonucunda her iki grubun akran koçluğuna ilişkin görüşlerinin olumlu, olumsuz ve öneri başlıkları altında toplandığı görülmüştür. Bu başlıklar altında ortaya çıkan kodlar ve temalar Tablo 2'de sunulmaktadır.

Tablo 2

Koçlarının Uygulamaya Yönelik Olumlu Görüşleri

\begin{tabular}{lll}
\hline Temalar & Kodlar & $f$ \\
\hline \multirow{3}{*}{ Bölüm içi etkileşim } & Sinıflar arası iletişimin artması & 2 \\
& Zümre öğretmeni bilinci oluşması & 2 \\
Kişiler arası etkileşim & Bölüm dinamiğinin artması & 2 \\
& Yeni arkadaşlar edinmek & 4 \\
Akademik gelişim & Kişilerarası iletişim becerileri geliştirmek & 3 \\
& Bilgi tekrarı & 3 \\
& Öğretirken öğrenmek & 2 \\
Görüş ve deneyim paylaşma & Teorinin pratiğe dönüşmesi & 2 \\
& Danışanların yaratıcı fikirlerinden meslekte yararlanma & 5 \\
Mesleki gelişim & Fikir alışverişinde bulunmak & 4 \\
& Deneyim paylaşmak & 2 \\
Duyuş̧sal gelişim & Mesleki olarak yol aldığını görmek & 2 \\
& Mesleki donanımın artması & 3 \\
Üst düzey zihinsel beceriler & Öğretmenliğe daha hazır hissetmek & 2 \\
& Özgüven kazanmak & 4 \\
& Sorumluluk duygusunun gelişmesi & 3 \\
& Yaratıcıllı̆ı̆ gelişmesi & 2 \\
& Eleştirel düşünmenin gelişmesi & 3 \\
\hline
\end{tabular}


Tablo 2'de görüldüğü gibi koçların akran öğretimine yönelik olumlu görüşleri bölüm içi etkileşim $(f=6)$, kişiler arası etkileşim $(f=7)$, akademik gelişim $(f=7)$, görüş ve deneyim paylaşma $(f=11)$, mesleki gelişim $(f=7)$, duyuşsal gelişim $(f=7)$ ve üst düzey zihinsel beceriler $(f=5)$ temaları altında toplanmıştır.

Koçların olumlu olarak değerlendirdikleri durumlardan biri, bölüm içi etkileşimdir. Sınıflar arası iletişimin artmasından $(f=2)$, aynı zümrenin öğretmenleri olacaklarını fark etmelerinden $(f=2)$ ve bölüm ilişkilerinde dinamik bir sürecin yaşanmasından $(f=2)$ memnun kalmışlardır. "Süreç bittikten sonra keşke diğer dersler için de böyle çalışmalar yapılsa diye düşündüm. Çünkü aynı zümrenin adayları olarak sınıflar arası iletişim çok önemlidir." (K1). "Yapılan görüşmeler, fikir alışverişleri bana, meslek hayatında yaşanacak zümre toplantılarını anımsatmıştı." (K4). "Bu çalışma yeni insanlarla tanışmak için bir firsat yarattı. Aynı bölüm öğrencisi olmamız, bölümümüzün dinamiğini artırdl." (K6).

Kişiler arası etkileşim de koçların olumlu değerlendirdiği bir unsur olmuştur. Çalışmalar sırasında yeni arkadaşlar edinmekten $(f=4)$ ve iletişim becerilerini geliştirmekten mutlu olmuşlardır $(f=3)$. "Danışanlarımızla fikir alışverişi, birbirimizi tanımamızı da sağladı. Böylece bu çalışma sayesinde dost edinmiş olduk. Belki de en olumlu yanı buydu." (K1). "Başkalarına yollar göstermek, onlara fikirler sunmak beni hem girişimcilik açısından hem de sosyal iletişim becerisi açısından olumlu etkiledi." (K2).

Koçlar bu çalışmanın akademik gelişimlerine katkısının; bilgileri tekrar etme $(f=3)$, öğretirken öğrenme $(f=2)$ ve teorik bilgileri pratiğe aktarma $(f=2)$ yoluyla gerçekleştiğini ifade etmişlerdir:

İki sene önce öğretmenliğe dair sadece teorik bilgilerim varken hem kendi sunumlarım hem de arkadaşlarımın sunumlarına yardımcı olmam sonucunda birçok farklı uygulama gördükçe teoride öğrendiğim bilgileri nası pratiğe dökebileceğim konusunda da bilgilendiğimi görebiliyorum (K2).

Akran koçluğu yapmanın görüş ve deneyim paylaşma açısından olumlu bir süreç olduğu belirlenmiştir. Bu süreçte koçların, danışanların yaratıcı fikirlerinden meslekte yararlanma $(f=5)$, fikir alışverişinde bulunma $(f=4)$ ve deneyimlerini paylaşma $(f=2)$ firsatı bulmaktan dolayı memnun oldukları görülmüştür: "Bazı arkadaşların ne kadar yaratıcı olduklarını gördük. O fikirler ileriki yıllarda işsimize yarayabilir. Karşılıklı güzel fikir alışverişlerimiz oldu." (K3). Deneyim paylaşma mikro öğretim sırasında yaşanabilecek heyecanı yenme, öğretimi hataya düşmeden yürütebilme noktalarına yoğunlaşmıştır. Koçlar hem duyuşsal hem bilişsel açıdan akranlarına destek olmaya çalışmışlardır:

Ben 3. sınıfta bu sürecin içindeyken heyecanımı yenmekte zorlanıyordum, yeni çalışmalar ortaya çıkartırken bu heyecanın nasıl yenilmesi gerektiğine ilişkin görüşlerim vardı; karşı tarafa bunları aktarmaya çalıştım. Biz uygulamaları yaparken bize sürekli rehberlik edecek biri olmadığından hataya düşme olasılığımız daha yüksekti. Oysa rehberlik çalışmaları yürütürken akranlarımın hataya düşebilecekleri yerlere dikkat çekme ve uygulamayı gerçekleştirmeden düzeltme imkânım oldu (K7).

Mesleki gelişim açısından koçlar mesleki olarak yol aldıklarını görmüşler $(f=2)$, akran koçluğu sürecinde mesleki donanımlarının arttığını belirtmişler $(f=3)$ ve kendilerini öğretmenliğe daha hazır hissetmişlerdir $(f=2)$. Öğretim sürecinde olabilecek aksamaları öngörebilecek kadar gelişmiş olduklarını görmüşlerdir: “Koçluk yaptığımız arkadaşların nerelerde eksik olduklarını görebildiğimizi fark ettik. Önceki biz ile koçluk yaptığımız zamandaki biz arasında olan farklılıkları gördük." (K3). Yapılandırmacı eğitimin sınıf içi uygulamalarını benimsemiş olduklarının farkına varmışlardır:

Artık çağdaş eğitim anlayışını benimsemiş bir öğretmenin neler yapması gerektiğini kavradım. İlk sunum dönemlerimde neler yapmam gerektiğini bilmiyorken, bu konu hakkında çok fazla düşünüyorken artık akran öğretimiyle arkadaşlarıma fikirler sundukça bazı noktaları hemen fark edebiliyorum ve daha kısa sürede daha başarılı çözümler ortaya çıkarabiliyorum (K2).

Yukarıdaki gelişmeler öğretmen adaylarının kendilerini mesleğe daha hazır hissetmelerini sağlamıștır. Akran koçları duyuşsal açıdan da gelişim gösterdiklerini belirtmişlerdir. Özellikle öğretmenlik mesleğini yapabileceklerine yönelik öz güven duygusu $(f=4)$ ve danışanlarına karşı hissettikleri sorumluluk duygusu $(f=$ 3), öğretmen adayları tarafından bu çalışmanın olumlu bir katkısı olarak değerlendirilmiştir: “Mesleğimize karşı inanılmaz öz güven depoladık. Artık ben bu işi yapabilirim, diyebiliyoruz." (K1).

Koçların olumlu görüşleri arasında, üst düzey zihinsel beceriler açısından gelişimlere de yer verdikleri belirlenmiştir. Özellikle yaratıcılıklarının $(f=2)$ ve eleştirel düşünmenin $(f=3)$ geliştiğini ifade etmişlerdir: “Koçluk yaptı̆̆ım kişilerle yapabilecekleri etkinlikler, ortaya çıkacak çalışma üzerine beyin fırtınası yapmak yaratıcı düşünmemi etkiledi ve zihnimde yeni fikirler oluşmasını sağladı." (K7). Eleştirel düşünmenin gelişimi hem uygulama öncesi görüş alışverişi sırasında karşı tarafa öneriler sunarken yaşanan tartışmanın hem de uygulama sonrasında ders gözlemine yönelik yorumların bir sonucu olarak ifade edilmiştir:

Bazen tasarımda yanlış bir şey görünce bunun neden yanlış olduğunu anlatabilmek için görüşlerimin dayanaklarını belirtmem gerekiyordu. Aksi hâlde kişisel beğenilerime dayalı olarak konuştuğumu düşünebilirdi (K5). 
Ders gözlemleri sonunda nelerin iyi olduğunu, nelerin geliştirilmesi gerektiğini söyleyebilmek için gözlemimi çok dikkatle yaptım. Gözlemlerimi nedenleriyle birlikte açıklamaya dikkat ettim. Bu çalışma benim eleştirel düşünme ve düşündüklerimi tam olarak aktarabilme konusunda kendimi geliştirmemi sağladı (K6).

Tablo 3

Koçlarının Olumsuz Görüşleri

\begin{tabular}{llc}
\hline Temalar & Kodlar & $f$ \\
\hline \multirow{2}{*}{ Koçluğun yanlış anlaşılması } & Çalışmayı koçların yapmasının beklenmesi & 3 \\
& Danı̧anların sorumluluk almaktan kaçmaları & 1 \\
Danışanların iş birlikli çalışmaya uygun davranmamasıı & Danışanların kendi fikirlerinde ısrarcı olmaları & 2 \\
& Danşanların basit işler yapmakta ısrarcı olmaları & 2 \\
Zamanlama & Vakit ayırmakta zorlanmak & 2 \\
Yaratıcılığı engelleme & Sürekli telefonla aranmak & 2 \\
\hline
\end{tabular}

Tablo 3'te sunulduğu üzere, akran koçlarının çalışma sürecine ilişkin olumsuz görüşlerinin koçluğun yanlış anlaşılması $(f=4)$, danışanların iş birlikli çalışmaya uygun davranmaması $(f=5)$, zamanlama $(f=4)$ ve yaratıcılı̆̆ engelleme $(f=2)$ temalarında toplandığı görülmüştür.

Koçluğun, danışanlar tarafından yanlış anlaşıldığını düşünen öğretmen adayları, danışanların çalışmanın bütün sorumluluğunu koçlardan beklemesinden $(f=3)$ ve kendi sorumluluklarını yerine getirmekten kaçınmalarından $(f$ =1) rahatsız olmuşlardır:

Bazen arkadaşlarımın tüm fikirleri bizim sunmamızı istediğini gördüm. Yani onlara her şeyi hazır olarak sunalım, her şeyi araştıralım, eksiksiz bir plan yapalım, onların tüm sorularına cevaplarımız olsun ve onlara sadece sunum yapmak kalsın istediklerine tanik oldum (K3).

Danışanların iş birlikli çalışmaya uygun davranmaması temasında danışanların kendi fikirlerinde 1srarcı olmaları $(f=2)$ ve basit bir çalışma yapmaya yönelik olmaları $(f=2)$, akran koçları tarafından sürecin olumsuz özellikleri arasında görülmüştür. Bazı danışanların koçlarla çalışmayı, işi kolaylaştırmak olarak gördükleri ve ortaya çıkarılacak ders sunumunun basit bir teknikle yapılmasını talep etmeleri, koçlar tarafından olumsuz karşılanmıştır: "Danışanlarımdan biri durmadan basit bir etkinlik olsun, basit bir teknik olsun diyordu." (K8). Danışanların yapılacak çalışma için esnek olmaması, kendi fikrini çok iyi bulması, koçların ise öngörülerinin onlardan farklı olması durumunda danışanlara bunu anlatmakta zorlandıkları görülmüştür:

... Sonuç itibariyle ortaya çıkacak çalışma onlarındı ve son karar onlara aitti. Ancak fikirleri iyi bir çalışma ortaya koymak için yetersizdi. Bu durumda yalnız görüş bildirmem yetmiyordu, onu ikna etmek için görüşümü temellendirmem, neden böyle düşündügümü açıklamam gerekiyordu. Bu iletişim bazı kişilerle çalışmalarımda yorucu olabiliyordu (K9).

Zamanlama temasında akran koçları vakit ayırmakta zorlandıklarını $(f=2)$ ve sürekli telefonla aranmaktan rahatsız olduklarını $(f=2)$ belirtmiş̧lerdir. Akran koçları son sınıf öğrencileri oldukları için kendi dersleri ve okul deneyimi çalı̧̧maları arasında alt sınıftaki danışanlarına zaman ayırmakta güçlük çekmişlerdir: "Çalışmalar sırasında derslerimiz, uygulamal derslerimiz, sinav çalışmalarımız, okul deneyimimiz, ödevlerimiz gibi kendi sorumluluklarımız olduğu için vakit ayırırken çok zorlandık." (K5). Danışanların toplantılar dışında koçları sık sık telefonla arayıp sorular sormaları, çalışmanın olumsuz görünen yönlerinden biridir: "Sürekli telefon ile soru sorulmasl, yoğunluğumuz arasında ekstra onlara zaman ayırmamız, bizim için zor oldu." (K4).

Akran koçluğu çalışmalarının olumsuz görülen bir yönü de danışan öğrencilerin kendi ders tasarımları konusunda yaratıcı olmalarının engellenmesine $(f=2)$ yöneliktir:

2. veya 3. sınıf öğrencileri, bir Türkçe dersi kazanımına uygun etkinlik, yöntem ve teknikleri kendileri bulabilmeli ve hayata geçirebilmeli. Öğretmen adayının koçlarla çalışması, o kişinin dersin her konusu ile ilgili özgün bir fikir sahibi olması önünde bir engeldir (K7).

Akran koçluğu sürecinde karşılaşılan sorunların giderilmesi ve sonraki çalışmaların daha sorunsuz yürütülebilmesi için koçların önerilerinin neler olduğu belirlenmiştir. Koçların önerileri, Tablo 4 'te sunulmuştur. 
Tablo 4

Akran Koçlarının Önerileri

\begin{tabular}{llr}
\hline Alt Temalar & Kodlar & $f$ \\
\hline \multirow{4}{*}{ Planlama } & Toplantı gün ve saatleri dersin hocası tarafindan oluşturulmalı. & 3 \\
& Çalışmalar için ortak zamanı dikkate alan bir plan yapılmalı. & 3 \\
& Okul yönetimleri koçlara esneklik sağlamalı. & 2 \\
& Koçlar dersin öğretmenine çalışmanın gidişatı hakkında rapor sunmalı. & 2 \\
Danışan nitelikleri & Danışanlar öğretim planı taslağı oluşturduktan sonra koçlarla çalışmaya başlamalı. & 2 \\
Koçların nitelikleri & Grup çalışması yapabilecek kişiler katılıalı. & 2 \\
& Yardım almak isteyen öğrenciler katılmalı. & 3 \\
\hline
\end{tabular}

Tablo 4'te görüldüğü gibi koçların önerilerinin planlama $(f=12)$, danışan nitelikleri $(f=5)$ ve koçların nitelikleri $(f=3)$ temalarında toplandı̆̆ belirlenmiştir.

Planlama temasında toplantı gün ve saatlerinin dersin hocası tarafından oluşturulması $(f=3)$, çalışmalar için ortak zamanı dikkate alan bir ders planı yapılması $(f=3)$, okul yönetimlerinin koçlara esneklik sağlaması $(f=2)$, koçların dersin öğretmenine çalışmanın gidişatı hakkında rapor sunması $(f=2)$, danışanların öğretim planı taslağ oluşturduktan sonra koçlarla çalışmaya başlaması $(f=2)$, önerilmiştir. Bu önerilerin ilk üçü alt ve üst sınıf öğrencilerinin farklı ders programları nedeniyle birlikte çalışma zamanını ayarlamalarından kaynaklanan güçlüklerle ilgilidir ve zamanlama konusunda yaşanılan sorunların çözümüne yöneliktir:

Akran öğretimi için bir araya gelen arkadaşlar kendi aralarında toplantı günleri ve saatleri oluşturmalılar. Bu sayede soracakları, akıllarına takılan bir durumu sadece o toplantıda soracakları için onun dışında sürekli arama, mesaj atma gibi bir durum olmayacaktır (K4).

Koçların, dersin öğretmenine çalışmanın gidişatı hakkında rapor sunması önerisi danışanların koçluğu yanlış anlamalarından veya iş birlikli çalışmaya uygun davranmamalarından kaynaklanan sorunların çözümüne yöneliktir:

Akran öğretiminin daha sistemli olabilmesi için dersin öğretmeni koçlarla iletişime geçmeli ve gidişat öğrenmeli. Çünkü çoğu kiși tüm ödevini koçuna yaptırıp sadece tahtaya çıkıp anlatmak istiyor. Bunu önlemek için koçlar mutlaka dersin öğretmeni ile iletişime geçip durumu bildirmeli (K7).

Danışanların öğretim planı taslağı oluşturduktan sonra koçlarla çalışmaya başlaması önerisi ise, her aşamada işi koçların yapması beklentisini ortadan kaldırmaya yöneliktir:

Koçluk yapanlar hazır bir şablon sunmamalı. Sunumu yapacak olanlara nasıl araştırılacağına dair yollar göstermeli, seçenekler sunmalı ve arkadaşımız araştırmalarını yaptıktan ve bir taslak oluşturduktan sonra koça göstermeli. Koç eksik veya güzel gördüğü yerleri belirtmeli, birlikte düzeltmeliler (K8).

Danışan nitelikleri temasında grup çalışması yapabilecek kişilerin akran koçluğu çalışmasına katılması $(f=2)$ ve yardım almak isteyen öğrencilerin katılması $(f=3)$ önerileri yapılmıştır. Bu önerilerin gerekçelerinden biri, danışanların akran koçlarına yeterince güvenmemesidir: "İş birlikli bir çalışmada taraflardan biri diğerine güvenmeyince başarılı bir çalışma ortaya çıkmıyor.” (K5). Başka bir gerekçe de bazı danışanların koçlarıyla yaptıkları çalışmayı son anda bütünüyle değiştirip bambaşka bir ders sunumu yapmasıdır:

$\mathrm{Bu}$ süreçte 2 kişiyle çalıștım. Arkadaşlarımdan biri hazırladığımız etkinliği, dersin akışını ve programı değiştirmiş̧i. Hazırladığımız içerik gayet güzel ve orijinaldi ama o bağımsız hareket etti ve başarılı bir sunum yapamadi $(\mathrm{K} 1)$.

Koçların nitelikleri temasında koçların öğrenci olduklarını unutmamalarına yönelik $(f=3)$ öneriler sunulmuştur. $\mathrm{Bu}$ önerinin gerekçesi, danışanların her türlüyü bilgiyi koçlardan almaya çalışmasına ve koçların alt sınıftaki danışanların deneyimsizlikleri nedeniyle daha otoriter davranmalarına dayanmaktadır:

Birden fazla fikir olmalı, tek bir fikir üzerinden gidilmemeli. Seçenekler arasından en uygunu seçilmeli. Koçlar kendi görüşlerinde 1srarcı olmamalı. Koç da bu süreçte bir öğrenci olduğunu ve kendisinin de bir şeyler öğrendiğini unutmamalı (K3).

Koçlardan başka danışanların da sürece yönelik görüşleri alınmıştır. Danışanların çalışmaya yönelik olumlu görüşleri Tablo 5 'te sunulmuştur. 
Tablo 5

Danışanların Akran Koçluğu Uygulamasına Yönelik Olumlu Görüşleri

\begin{tabular}{llc}
\hline Temalar & Kodlar & $\boldsymbol{f}$ \\
\hline \multirow{3}{*}{ Öğretime hazırlık } & Öğretim öncesinde hataları düzeltme & 4 \\
& Deneyimli biri karşısında prova yapma & 4 \\
Mesleki gelişim & Daha kıssa sürede hazırlanma & 2 \\
& Öğretimin her aşamasında stratejik noktalar konusunda bilgilenme & 8 \\
Görüş ve deneyim paylaşımı & Kalıcı öğrenme & 3 \\
& Sinıf yönetiminde etkili olma & 3 \\
Duyuşssal gelişme & Deneyim paylaşımı yapma & 8 \\
& Görüş alışverişi yapma & 6 \\
Öğrenmenin doğası & Kendine güven kazanma & 6 \\
& Heyecanı yenme & 3 \\
İletişim & İş birlikli öğrenme & 3 \\
& Beyin firtınası yaparak öğrenme & 3 \\
& Eğlenerek öğrenme & 2 \\
& Her zaman ulaşabilme & 7 \\
\hline
\end{tabular}

Danışanların akran öğretimine yönelik olumlu görüşleri; öğretime hazırlık $(f=10)$, mesleki gelişim $(f=14)$, görüs ve deneyim paylaşımı $(f=14)$, duyuşsal gelişim $(f=9)$, öğrenmenin doğası $(f=8)$ ve iletişìm $(f=15)$ temalarında toplanmaktadır.

Danışanlar öğretime hazırlık temasında öğretim öncesinde hataları düzeltme $(f=4)$, deneyimli biri karşısında prova yapma $(f=4)$ ve daha kısa sürede hazırlanma $(f=2)$ firsatı bulmaktan memnun olmuşlardır. Koçlar hem plan düzeyinde hem de sunumdan önce prova esnasında olası hataları görüp danışanların öğrencilerle ders işlerken bu hataları yapmamalarını sağlamışlardır: "Planı hazırlayıp sunduğumda bana yanlışlarımı gösterip düzeltmemi sağladı." (D6). "Daha önce aynı yoldan geçmiş birinden yapacă̆ım hataları hiç yapmadan düzeltme şansı buldum." (D10). Koçların deneyimli olmaları, danışanların hazırlıklarını daha kısa sürede tamamlamalarını sağlamışıı: "Arkadaşımın tecrübesinden dolayı sunum hazırlama sürecim kisa bir zamanda, olumlu ve verimli bir şekilde sonuçlanmıştır." (D7).

Danışanlar, mesleki gelişim açısından öğretimin her aşamasında stratejik noktalar konusunda bilgi sahibi olmaktan $(f=8)$, sürecin kalıcı ögrenme sağlamasından $(f=3)$ ve sınıf yönetiminde etkili olmaya yönelik stratejiler $(f=3)$ geliştirmiş olmaktan dolayı memnuniyetlerini bildirmişlerdir. Öğretimin her aşamasında stratejik noktalar konusunda bilgi sahibi olmaya yönelik bir memnuniyet örneği, görüş formlarına şöyle yansımıştır:

Hazırlamış olduğum planı irdeleyerek varsa yanlış noktalarım, onları giderdi. Planı uygulamam ve sunuma hazırlanmam için bir prova gerçekleştirmemi istedi. Bu prova esnasında derse giriş kısmında yapmam gerekenleri söyledi. Derse giriș esnasında dikkat çekici olmamı böylelikle öğrencilerin konuyu daha dikkatli bir şekilde dinleyeceklerini, bu konuyu günlük hayatla bağdaştırarak öğrendiklerinin önemli ve kullanılabilir bilgiler olduklarını öğrencilere hissettirmem gerektiği konusunda beni bilgilendirdi. Etkinlik konusunda görüşlerini beyan ederek ortak bir sonuca ulaşmamda yardımcı oldu. Dersi bitirirken dikkat etmem gereken hususlar konusunda ve verdiğim ödevin kazanımla ilgili olması gerektiği konusunda beni bilgilendirdi (D2).

Akran koçluğu sürecindeki bilgi ve deneyim paylaşımlarının, yapılan tartışmaların kalıcı öğrenme sağlaması yönüyle memnuniyet yarattığı görülmüş̧ür: "İki taraf açısından ömür boyu kullanılacak bilgiler ve tecrübeler oluşturuyor." (D10). Koçların planlama ve planı uygulamadan başka sınıf yönetimi konusunda da danışanları hazırlamaya çalışmaları memnuniyetle karșılanmıştır: "Sinıfina hâkim bir ögretmen olduğumu gösterebilmem konusunda da çok güzel fikirler aldım." (D10).

Görüş ve deneyim paylaşımı temasında koçların deneyimlerini danışanlarla paylaşmaları $(f=8)$, karşılıklı görüş alışverişi yapmaları $(f=6)$ danışanları memnun etmiştir. Koçların deneyimli olması yapılacak çalışmanın hatasız olmasını sağlayan bir unsur olmuştur: "Onların deneyimlerinden, bilgilerinden yararlanmam bence benim için çok büyük bir șanstt. Böylelikle sunum esnasında doğruyu ve yanlıșl ayırt edebildim.” (D2). Ders sunumu konusunda farklı farklı seçenekler arasında hangisinin daha iyi olabileceği konusunun tartışılması konuya farklı açılardan bakabilme olanağı sağlamıştır: "Örneğin ben bir fikir atıyorum ortaya ve onlar bunun olumlu olumsuz yönlerini eleştiriyorlar. Yeni fikirler edinmemi sağllyorlar. Bu şekilde de ortaya daha doğru şeyler çıklyor." (D1).

Duyuşsal gelişim açısından akran koçluğu danışanlar tarafından kendilerine güveni artıran $(f=6)$ ve sunum heyecanını yenmelerini sağlayan $(f=3)$ bir süreç olarak değerlendirilmiştir. Koçların danışanların fikirlerini 
övmeleri, işi en şekilde yapabileceklerine yönelik değerlendirmeleri, danışanların öğretim becerileri konusunda kendilerine güvenmelerini sağlamıştır: "Onların deneyimlerinden yola çıkarak bir şeyler ögrendim ve kendi yolumu oluşturdum. Fikirlerimin deneyimli arkadaşlarım tarafindan beğenilmesi sayesinde kendime güven kazandım. ”(D2). İlk defa sunum yapmanın heyecanını yaşayan öğretmen adayları, koçların motive edici sözleriyle ve heyecanı yenmeye yönelik stratejiler öğretmeleriyle heyecanlarını yenmeyi başarabilmekten memnun olmuşlardır: "Sunumumum iyi geçeceğine dair motivasyon konuşmaları yaptı ve heyecanımı yenmem için de taktikler sundu." (D3). Sunum öncesi deneyimli akranlarına prova yapmaları da heyecan ile başa çıkmakta etkili olmuştur: "Sunumumdan önce onlara sunum yapmamı isteyerek heyecanımı yenmemi sağladılar." (D6).

Öğrenmenin doğası temasında akran koçluğunun iş birlikli öğrenme $(f=3)$, beyin firtınası yaparak öğrenme $(f=$ 3) ve eğlenerek öğrenme $(f=2)$ ortamları yaratmasından dolayı öğretmen adaylarının memnun kaldıkları görülmüştür. İş birlikli öğrenme "birçok fikrin ortaya atılması ve bunun sonucunda da sentez bir fikrin ortaya çıkmasını" (D1) sağlamıştır. Planın hazırlanışından uygulanmasına, sınıf yönetiminden beden dilinin kullanıma kadar pek çok noktada deneyimli akranlarla yapılan beyin fırtınası, daha iyi bir ders sunumuna hazırlanmayı sağlamıştır: "Yapılan beyin firtınalarında plan olsun, etkinlikler olsun, jest ve mimikler olsun diğer davranışlarımız olsun tartışıldı ve ortaya yine olumlu şeyler çıktı. Bu işin en önemli kısmı beyin firtınası diye düşünüyorum." (D10). Danışanlar birçok yeni bilgi edinirken aynı zamanda eğlenceli bir öğrenme ortamı deneyimlemişlerdir: “Ben koçumla çalışırken hem öğrendim hem de eğlendim.” (D2).

İletişim temasında koçlara her zaman ulaşabilmenin $(f=7)$, hocalara sorulamayanları akranlara daha rahat sorabilmenin $(f=4)$ ve arkadaşlık ilişkileri geliştirmenin $(f=4)$ memnuniyet yarattığı belirlenmiştir.

Koçlara her zaman ulaşabilmek, akran desteğini sadece planlanan günlerde yapma sınırı olmadan her zaman danışabilmeyi sağlamıştır: "İstediğimiz her anda iletişime geçip yardım isteyebiliyoruz." (D4). Akranlarla yaşanan yoğun iletişim, yardımlaşma ve öğrenme ortamı yeni arkadaşlıklar edinmelerini sağlamıştır: "Akranla çalışmam doğrultusunda yeni arkadaşlıklar edindim.” (D2). Öğretmen adayları akranlarına sık sık ulaşabilmelerini avantaj olarak görmüşler, hocalarına soramadıkları soruları rahatça sorabilmişlerdir. Aynı sıklıkta dersin hocasına soru sormanın hem hocaya yükleyeceği yükten dolayı hem de çekindikleri için mümkün olmadığını ifade etmişlerdir:

Sorun yaşadığım noktalarda hiç çekinmeden danışabiliyordum. Bu çalışmayı belki de ders hocamızla yapsaydık o kadar kişi sürekli bir kişiye soracağından hem hocamızın bu durumda bunalacağını hem de bizim baz noktalarda çekindiğimiz için soramayabileceğimizi düşünüyorum (D9).

Danışanların akran koçluğu sürecinde yaşadıkları olumsuz durumlar da belirlenemeye çalışılmıştır. Yapılan belirlemeler Tablo 6'da sunulmuştur.

Tablo 6

Danışanların Akran Koçluğuna Yönelik Olumsuz Görüşleri

\begin{tabular}{lll}
\hline Temalar & Kodlar & $f$ \\
\hline \multirow{2}{*}{ Özgün düşünceyi engelleme } & Koçların kendi fikirlerini dayatmaya çalışması & 2 \\
& Yaratıcılığı engellemesi & 1 \\
\multirow{2}{*}{ Zamanlama } & Ortak bir zaman yaratıp görüşmeye çalışmak & 2 \\
& Koçların vakit yaratmakta zorlanmaları & 3 \\
\hline
\end{tabular}

Tablo 6'da görüldüğü gibi akran koçluğu sürecine ilişkin olumsuz görüşler özgün düşünceyi engelleme $(f=3)$ ve zamanlama $(f=5)$ ile ilişkilidir.

Özgün düşünceyi engelleme durumu koçların kendi fikirlerini dayatmaya çalışması $(f=2)$ ve yaratıcılığ engellemesi $(f=1)$ ile ilişkilendirilmiştir. Koçların danışanlarıyla fikir ayrılıkları yaşadıkları durumlarda kendi fikirlerinde 1srarcı olmaları sorun yaratmıştır: "Bazı noktalarda fikir alışverişinde çakışılan yerler olduğunda akranın pek fazla sözünden çıkılmasını istenmemesi gibi durumlar ufak anlaşmazlıklar ortaya çıkarabildi." (D3). Bir öğretmen adayı da zorlandıkları noktalarda koçların çözüm üretmelerini yaratıcılığı engelleyen bir sorun olarak değerlendirmiştir:

Şahsi görüşümce yararlı olmayan tarafı, öğrencinin yaratıcılığının engellenmesidir. Çünkü öğrenci zorlandığı yerlerde kafa yorup çözüm üretmektense akranına danışıp fikir sahibi olmaktadır. Bu da öğrencilerin biraz hazırcılığa alışmasına sebep olabilmektedir (D5).

Zamanlama temasında ortak bir zaman yaratıp görüşmeye çalışmak $(f=2)$ ve koçların vakit yaratmakta zorlanmaları $(f=3)$, akran koçluğu sürecine ilişkin sorunlar olarak belirlenmiştir. 3. ve 4. sınıf öğrencilerinin bir araya geldikleri bu çalışmada sınıfların programı birbirinden bağımsız hazırlandığı için ortak bir boş zaman bulmaları zor olmuştur. Bu nedenle bazen görüşebilmek için biri diğerini beklemek zorunda kalmıştır. Bu da danışanlar tarafından keyfi bir durum gibi algılanmıştır: “Karşımızdaki tarafın müsait olmasını beklemek biraz 
onun keyfini beklemek gibi oluyor." (D8). Koçların KPSS hazırlığı, okul deneyimine gitmeleri ve derslerinin devam etmeleri nedenlerine bağlı olarak vakit yaratmakta zorlanmaları, danışanlar tarafından süreçte yaşanan sorunlar arasında yer almıştır:

Son sınıf öğrencisi oldukları için sınava hazırlanıyorlardı, üzerlerinde bunun stresi vardı ve her bir dakika onlar için çok önemliydi. Ama ne yazık ki bu streslerini çoğu zaman bize de yansitıyorlardı. Zaman herkes için önemli bir kavramken sınava hazırlık sürecinde olduklarından dolayı onlar için daha önemli olduğundan bazen işi aceleye getirebiliyorlar ve onlara rahatsızlık veriyormuşuz gibi hissettirebiliyorlardı (D4).

Akran koçluğu çalışmasının sorunsuz yürütülmesi için danışanların önerileri de belirlenmiştir. Yapılan belirlemeler Tablo 7'de sunulmuştur.

Tablo 7

Danışanların Önerileri

\begin{tabular}{llc}
\hline Temalar & Kodlar & $f$ \\
\hline & Uygulama derslerinin tamamında deneyimli akranla çalışma yönteminin kullanılması & 5 \\
& Yönetim tarafından uygun görüş̧e saatleri yaratan bir ders programı yapılması & 3 \\
Planlama & İkili ilişkileri iyi olan öğrencilerin birlikte çalışması & 2 \\
& Koç ve danışan eşleştirmesinin hoca tarafından yapılması & 2 \\
& Akran çalışmalarının iki koç ile yürütülmesi & 2 \\
& Danışanların öğretim için tüm süreçlerini tasarladıktan sonra bir akran koçundan fikirler & 1 \\
& alması & 2 \\
Koçların nitelikleri & Gerçekten bilgili ve donanımlı kişilerin koçluk yapmaları & 3 \\
Danışan beklentileri & Koçların gerçekten gönüllü olanlardan seçilmesi & 2 \\
\hline
\end{tabular}

Tablo 7'de görüldüğü üzere, danışanlar planlama $(f=13)$, koçların nitelikleri $(f=5)$ ve danışanlardan beklentiler $(f=3)$ noktalarında öneriler sunmuşlardır. Planlama temasında uygulama derslerinin tamamında deneyimli akranla çalışma yönteminin kullanılması $(f=5)$, yönetim tarafından uygun görüşme saatleri yaratan bir ders programı yapılması $(f=3)$, koç ve danışan eşleştirmesinin hoca tarafından yapılması $(f=2)$, akran çalışmalarının iki koç ile yürütülmesi $(f=2)$, ikili ilişkileri iyi olan öğrencilerin birlikte çalışması $(f=2)$ ve danışanların öğretim için tüm süreçlerini tasarladıktan sonra bir akran koçundan fikirler alması $(f=1)$ önerileri danışanlar tarafından sunulmuştur. Uygulamalı derslerde ilk kez sunum yapacak olan öğrenciler, karşılaştıkları sorunların çözümünde deneyimli akranların desteğine ihtiyaç duymaktadırlar. Bu nedenle bütün uygulamalı derslerde üst sınıftan akran desteği verilmesini önermektedirler:

Çünkü ilk defa sunum yapacak olanlar oluyor ve hem heyecandan hem de nasıl yapılacağını bilmemekten dolayı birçok sorun ortaya çıkabiliyor. Ama bizden daha iyi bilen kişilerin de yardımını alarak el birliği ile ortaya daha güzel ürünler çıktığını düşünüyorum (D8).

Öğretmen adayları tarafından, zamanlama probleminin çözümüne yönelik ise, uygun görüşme saatleri yaratan bir ders programı yapılması önerilmiştir:

Çalışmalarımızda en çok zorlandığımız şey, ortak bir boş zamanımız olmadığ 1 için görüşme planlaması yapmaktı. Öğrencilere okul yönetimince biraz esneklik sağlansa, ders programları buna göre ayarlansa yapılan çalışmaların çok yüksek seviyelerde başarılar getireceğine inanıyorum (D4).

Görüş alışverişleri sürecinde koçların daha baskın bir tutum sergilemeleri sorununa yönelik olarak ikili ilişkileri iyi olan öğrencilerin birlikte çalışması önerilmiştir: "Bölüm içinde herkes az çok birbirini tanıyor. Özelikle birbirine yakın olan, ikili ilişkileri iyi olan öğrencilerin bir araya gelmesi olumlu olur." (D9). Bu çalışmada danışanlarla koçların bir araya gelip tanışmaları sağlanmıştır. Ancak öğrenciler kimlerle çalışacaklarını kendi aralarında belirlemişlerdir. Bu durumda önceki yıl performansları çok beğenilen öğrencilerle çalışmaya yönelik talep fazla olmuştur. Bu nedenle öğrenciler eşleştirmenin dersin hocası tarafından yapılmasını önermişlerdir:

Öğrencilerin koçlarını kendilerinin seçmesindense dersin hocasının dağıtımı yapmasının daha doğru olacağını düşünüyorum. Çünkü daha önceki senede bu konuda en iyi olanlara karşı bir yığıllma oldu ve böyle olunca hem o kişi rahatsız oldu hem de belki de çok daha yararlı olabilecekken fazla kişiye yardım etmesinden dolayı verimin düştüğünü ve bir yerden sonra da yapılan işin aman bir an önce bitsin gitsin havasına döndüğünü düşünüyorum (D9).

Akran çalışmalarında farklı görüşleri alabilmek, konuya farklı açılardan bakabilmek açısından iki koç ile çalışmaların planlanması da öneriler arasında yer almıştır: "Bence akran çalışmalarında iki kişi ile çalışmak daha yararlı olabilir çünkü farklı görüşler ve farklı bakış açıları oluyor.” (D3). Danışanların öğretim için tüm süreçlerini tasarladıktan sonra bir akran koçundan fikirler alması önerisi, yaratıcığın gelişimini engelleme kaygısı nedeniyle 
sunulmuştur: "Kendi fikirlerimizi geliş̧tirebilmek için öğretimin tüm süreçlerini tasarladıktan sonra bir öğretmen adayının fikirlerinden yararlanmak gerektiğini düşünüyorum." (D5).

Koçların nitelikleri temasında yanlış yönlendirmeler olmaması için "gerçekten bilgili ve donanımlı kişilerin koçluk yapmaları $(f=2)$ ve koçların gerçekten gönüllü olanlardan seçilmesi $(f=3)$ önerileri sunulmuştur: "Akran çalışmalarında gerçekten bilgili ve donanımlı kişilerin seçilmeli; aksi takdirde yanlış yönlendirmeler yaşanabilir.." (D3). "Akranla ögrrenme çalışmalarında gönüllü olarak koçların seçilmesi gerektiğini düşünüyorum. Çünkü bu işi gönüllü bir șekilde yerine getirenler daha fazla yarar sağlayacakttr." (D8). Danışan beklentileri temasında ise, danışanların koçları sadece yol gösterici olarak görmesi $(f=2)$ önerisi sunulmuştur: "Koçların sadece fikirleri gelişstirmede yol gösterici olması gerektiŏini düşünüyorum. Bu şekilde ortaya daha özgün çalışmaların çıkması sağlanacaktır." (D1).

\section{Sonuç ve Tartışma}

Karma yöntemle yapılan bu çalışmada akran koçluğunun öğretmenlik becerilerinin gelişimine etkisi araştırılmıştır. Yapılan analizler sonucunda plan yapma ve planı uygulama, derse giriş yapma, dersi geliştirme ve genel başarı boyutlarında akran koçluğu desteği alan deney grubu lehine anlamlı farklar belirlenmiştir. Konu alan bilgisi ve iletişim boyutlarında farkın kontrol grubu lehine olduğu, dersi kapatma boyutunda ise gruplar arasında anlamlı bir fark olmadığı görülmüştür.

Plan yapma ve planı uygulama, derse giriş yapma, dersi geliştirme ve genel başarı boyutlarında deney grubunun daha başarılı bulunması, danışanların görüşlerinde belirlendiği gibi öğretime hazırlık ve mesleki gelişim açısından uygulamanın yararlı olması ile açıklanabilir. Plan boyutu; planda dersin bütün aşamalarına eksiksiz yer verme, planın bölümlerini açık ve net şekilde kazanımla ilişkili olarak yazma ve dersi plana uygun şekilde işleme ölçütlerini içermektedir. Derse giriş yapma boyutu; dikkati çekme/güdüleme, amacı belirtme ve önemi açıklama ölçütlerini içermektedir. Dersi geliştirme boyutu; kazanıma uygun araç ve gereçleri kullanma, uygun yöntem ve teknikleri kullanma, etkinlik hazırlama, yönlendirmeleri açıkça ifade etme, sorular sorma, dönüt verme, övgü ve yaptırımlardan yararlanma ve konuyu gerçek yaşamla ilişkilendirme ölçütlerini içermektedir. Danışanlar öğretim öncesinde deneyimli biri karşısında prova yaptıkları için söz konusu ölçütlerde hatalarını görme ve düzeltme olanağı bulmuşlar ve koçlarından öğretimin her aşamasına yönelik stratejik bilgiler edinmişlerdir. Koçlar hem planlamada hem de sunumdan önce prova esnasında olası hataları görüp danışanların öğrencilerle ders işlerken hata yapmamalarını sağlamışlardır. Akran koçluğunun öğretim becerilerini geliştirdiğini gösteren pek çok araştırma ile bu sonuçlar uyumludur (Arslan Dönmez, 2020; Göker, 2006; Kasapoğlu, 2002; Kavanoz ve Yüksel, 2010; Mirzeoğlu ve Özcan, 2015; Scott ve Miner, 2008; Vacilotto ve Cummings, 2007).

Konu alan bilgisi ve iletişim boyutlarında farkın kontrol grubu lehine olması, akran koçlarının daha çok öğretimi planlama ve öğretim becerileri konusunda danışanlara yol göstermeleri ile açıklanabilir. Ayrıca akran koçluğu çalışmalarının alan bilgisi üzerinde etkili olması, süreç içinde tekrarlayan çalışmalar sonucunda görülebilmektedir. Karakaya Cirit ve Aydemir (2019) alan bilgisi gelişimi ile akran koçluk sürecinde geçirilen zaman arasında güçlü bir ilişki olduğunu belirtmektedir. Koçluk desteğinin birkaç çalışmada tekrarlanması, akran koçluğu çalışmalarının alan bilgisinde etkili olması için gerekli görünmektedir. Bu araştırmada bir öğretim uygulamasına yönelik olarak akran desteği sağlandığı için konu alan bilgisi açısından uygulamanın etkili olmadığı düşünülmektedir. Araştırmanın nitel boyutunda koçlar kendilerinin de öğrenci oldukları hâlde her şeyi bilmelerinin beklenmesinden sıkıntı duyduklarını belirtmişlerdir. İçerik konusunda gerekli bilgileri araştırmayı, deney grubu öğrencilerinin görevi olarak görmüşlerdir. İletişim boyutunda öğrenciyi ciddiye alma, sözlü dili ve beden dilini etkili kullanma becerileri gözlenmiştir. Deney grubunu oluşturan danışanlar, koçlardan jest ve mimik kullanımına yönelik stratejiler aldıklarını belirttikleri hâlde iletişimde, kontrol grubu daha başarılı olmuştur. Bu sonuç, kontrol grubu öğrencilerinin iletişim becerilerinin uygulamalara başlamadan önce de daha iyi olduğunu düşündürmektedir. Araştırmanın sınırlılıklarından biri, ön test yapma olanağı olmamasıdır. Ön testte grupların özellikleri ölçülebilseydi son testte en azından grup içi bir gelişme olup olmadığı belirlenebilirdi.

Dersi kapatma boyutunda gruplar arasında anlamlı bir fark görülmemiştir. Bu aşamada dersi özetleme, kazanımı uygun strateji ile değerlendirme ve öğrencileri sonraki derse hazırlama açısından öğrenciler gözlenmiştir. Araştırmanın deneysel sürecine başlamadan önce aynı öğretim elemanı tarafından tüm öğrencilere mikro öğretim ve dersin yapılandırılması hakkında sunulan bilgilerin bu sonuçta etkili olduğu düşünülmektedir. Ayrıca akran desteği almayan öğrenciler kendi kendilerine neler başarabileceklerini görmek istediklerini belirtmişlerdir. Mikro öğretim uygulamalarında bütün bilgi ve becerilerini ortaya koymaya çalışmışlardır. Bazı boyutlarda fark görülmemesi ya da kontrol grubu lehine fark görülmesi öğrencilerin kendilerini geliştirme gayreti ile açıklanabilir.

Araştırmaya katılan öğrencilerin akran koçluğu uygulamasına yönelik görüşlerinin olumlu, olumsuz ve öneriler temalarında toplandığı görülmüştür. Koçlar bölüm içi etkileşim, kişiler arası etkileşim, akademik gelişim, görüş ve deneyim paylaşma, mesleğe hazır hissetme, duyuşsal gelişim ve üst düzey zihinsel beceriler bakımından uygulamayı olumlu değerlendirmişlerdir. Bununla birlikte koçluğun yanlış anlaşılması, danışanların iş birlikli çalışmaya uygun davranmaması, zamanlama ve yaratıcılığı engelleme bakımından olumsuz karşılanabilecek 
görüşler belirtmişlerdir. Koçlar olumsuzlukların giderilmesi için planlama, danışan nitelikleri ve koçların nitelikleri bakımından öneriler sunmuşlardır.

Danışanlar öğretime hazırlık, mesleki gelişim, görüş ve deneyim paylaşımı, duyuşsal gelişim, öğrenmenin doğası ve iletişim açılarından akran koçluğu uygulamasını olumlu bulmuşlardır. Özgün düşünceyi engelleme ve zamanlama açılarından olumsuz kabul edilebilecek görüşler belirtmişlerdir. Planlama, koçların nitelikleri ve danışan beklentileri açısından öneriler sunmuşlardır.

Koçlar ve danışanlar mesleki gelişim, görüş ve deneyim paylaşımı ve duyuşsal gelişim temalarında ortak olumlu görüşler belirtmişlerdir. Akran koçluğu sadece danışanların değil koçların da mesleki gelişimlerine katkıda bulunmuştur. Danışanlar öğretimin her aşamasına yönelik stratejik bilgiler edinmişler, sınıf yönetiminde etkili olduklarını görmüşler ve bu öğrendiklerinin kalıcı bilgiler olacağını belirtmişlerdir. Koçlar mesleki olarak yol aldıklarını görmüşler, mesleki donanımlarının arttığını ve mesleğe daha hazır hissettiklerini belirtmişlerdir. Mesleki kazanımların temelinde öğrencilerin birbirleriyle görüş ve deneyim paylaşımı yapmaları yer almaktadır. Duyuşsal olarak iki taraf da öğretmenlik mesleğini yapabileceklerine yönelik öz güven kazanmışlardır.

Danışanlar ayrıca öğretime hazırlık, öğrenmenin doğası ve iletişim temalarında akran koçluğuna yönelik memnuniyetlerini belirtmişlerdir. Öğretim öncesinde deneyimli biri karşısında prova yapmaları, daha kısa zamanda öğretim hazırlıklarını tamamlamalarını ve hatalarını düzeltme firsatı bulmalarını sağlamıştır. Uygulamanın iş birlikli öğrenmeye dayanması ve beyin firtınası yaparak en iyi öğretim için çeşitli seçenekleri gözden geçirmeleri, eğlenerek öğrenme olanağı sunmuştur. Özellikle akranları ile iletişim yollarının her an açık olması, hocalara sorulamayanları akranlara daha rahat sorabilme, danışanların karşılaştıkları problemleri çözebilmeleri için fırsat yaratmış ve arkadaşlık ilişkilerini de geliştirmiştir.

Koçlar açısından bölüm içi ve kişiler arası etkileşimin gelişmesi, akademik olarak gelişme ve üst düzey zihinsel beceriler geliştirme açılarından uygulama yararlı olmuştur. Bölüm içi etkileşim sınıflar arası iletişimi arttırmış, aynı meslekte aynı zümrenin adayları olacakları bilincini geliştirmiş ve birbirlerine mesleki açıdan katkı sağlayabileceklerini görmüşlerdir. Sürecin yoğun bir iletişime dayanması, ortak paydalarının aynı bölüm öğrencileri olmaları sonucunda arkadaşlık ilişkileri de gelişmiştir. Bilgi ve deneyimlerini tekrar etmeleri, öğretirken öğrenmeleri, teorinin pratiğe dönüşmesi için uygulamanın ortam yaratması koçlar açısından akademik gelişim sağlamıştır. Ayrıca üst düzey zihinsel becerilerin gelişimi açısından da uygulama yararlı bulunmuştur. Yaratıcı düşünmenin gelişiminde beyin firtınası yoluyla etkinlik tasarlamaya çalışmak etkili olmuştur. Eleştirel düşünmenin gelişiminde uygulama öncesi karşı tarafa öneriler sunma aşamasında yaşanan tartışmaların, uygulama sonrasında ise ders gözlemine dayalı olarak yapılan yorumların etkili olduğu görülmüştür. Her iki aşamada da yorumların nedenlere dayalı olarak yapılması uygulamanın eleştirel düşünmeyi geliştirici bir yönü olarak belirlenmiştir. Akran koçluğu uygulamasının öğrenmeye, iş birliğine ve öz güvene dayalı profesyonel gelişimi teşvik ettiğini (Alsaleh ve diğ., 2017), meslektaşlık duygusunu geliştirdiğini, geri bildirim ve tavsiye almanın, aynı deneyimleri paylaşmanın memnuniyet yarattığını (Kurtts ve Levin, 2000), öğretmen adaylarının öğretim yeterliklerini geliştirdiğini ve kendilerini görme firsatları sunarak onları daha iyi öğretmenler hâline getirdiğini (Kavanoz ve Yüksel, 2010; Vacilotto ve Cummings, 2007) belirten araştırmalarla ortak sonuçlara ulaşılmıştır.

Akran koçluğu uygulamasında danışanlar ve koçlar açısından ortak sorunlar, zamanlama ve yaratıcı düşünceyi engelleme ile ilişkilidir. 3. ve 4. sınıf öğrencileri ile yapılan bu çalışmada sınıfların ortak boş zamanlarının olmaması, bir araya gelmelerini zorlaştırmıştır. Danışanların sürekli olarak koçları telefonla aramaları, koçların vakit ayırmakta zorlanmaları, uygulamada karşılaşılan sorunların temel nedenleri arasındadır. Akran koçluğunda zamanlamanın problem olduğu başka araştırmalarda da görülmektedir (Çapan ve Bedir, 2019; Kurtts ve Levin, 2000). Danışanların öğretim tasarımına yönelik yaratıcı düşünceler geliştiremeyeceği endişesini iki taraf da dile getirmiştir. Bu endişenin temelinde bazı danışanların koçluğu yanlış anlaması sorununun yattığı söylenebilir. Danışanların sorumluluk almaktan kaçmaları ve çalışmayı koçların yapmasını beklemeleri, kendi tasarımlarını yaratıcı yapabilmelerinin önünde engel olabilir. Ayrıca koçların kendi görüşlerini dayatmaya çalışmaları da danışanlar açısından fikirlerinin bastırılması ile sonuçlanabilir.

Karşılaşılan zamanlama sorununun çözümü için danışanlar ve akranlar uygun görüşme saatleri yaratan bir ders programı yapılmasını önermişlerdir. Yaratıcılığın engellenmesi problemine yönelik olarak sunulan ortak çözüm önerisi, danışanların öğretim için tüm süreçlerini tasarladıktan sonra bir akran koçundan fikirler alması şeklindedir. Koçların kendi fikirlerini dayatmaya çalışmaları sorununa yönelik olarak danışanların, çalışmaların iki koç ile yürütülmesi önerisi etkili olabilir. Danışanların sorumluluk almaktan kaçmaları, her işi koçların yapmasını beklemeleri sorununa yönelik olarak dersin öğretmenine çalışmanın gidişatı hakkında rapor sunulması önerisi dikkate değerdir.

Sonuç olarak öğretmen adaylarının bir kazanıma yönelik plan yapma ve dersi yapılandırma becerileri kazanmasında akran koçluğunun etkili olduğu belirlenmiştir. Alınacak bazı tedbirlerle öğretmen adaylarını mesleğe hazırlamada akran koçluğundan etkili bir şekilde yararlanılabilir. Özellikle 21. yüzyıl öğretmenlerinin öğrenme ve yenilenme becerileri kapsamında geliştirmesi beklenen yaratıcılık, eleştirel düşünme, problem çözme, 
iletişim ve iş birliği becerileri kazanmalarında; yaşama ve mesleğe uyum sağlama kapsamında esneklik, sosyal beceriler, üretkenlik, liderlik becerileri kazanmalarında akran koçluğunun desteğinden yararlanılabilir.

Akran koçluğu uygulamasının etkili bir şekilde kullanılması için geliştirilen öneriler şunlardır:

1. Öğretmen adaylarının mesleğe hazırlıklarının bir parçası olarak akran koçluğu eğitim fakültelerinin öğretim programlarında resmi olarak yer almalıdır (Britton ve Anderson, 2010; Çapan ve Bedir, 2019; $\mathrm{Lu}, 2010)$.

2. Danışanların yaratıcı öğretim tasarımları yapabildiklerinden emin olmaları için öğretim planlarını yaptıktan sonra koçlarla çalışmaya başlamaları daha uygundur.

3. Öğretim öncesi görüşme aşamasında danıșanların sorumluluk almaktan kaçma ve koçların daha deneyimli ve bilgili olmaları nedeniyle baskın davranma eğilimleri belirlenmiștir. Danıșanların ve koçların süreçteki rollerini tam olarak benimseyebilmeleri açısından iyi bir eğitim almaları, hatta örnek birkaç çalışmayı izleyerek değerlendirmeleri sağlanmalıdır.

4. Çalışmalar sürecinde danıșanların ve koçların her aşamada neler yaşadıklarını kısa bir rapor hâlinde öğretim elemanına sunması, akranların daha tutarlı, beklentilere daha uygun şekilde davranması açısından işlevsel olabilir.

5. Ölçütlere dayalı gözlem, koçların eleştirel düşünmelerini sağlayan bir unsur olarak belirlenmiştir. Bu nedenle gözlem ölçütlerinin önceden belirlenmesi önerilmektedir.

6. Bu araştırmanın sınırlılıklarından biri ön test yapılmamış olmasıdır. Bu nedenle elde edilen sonucun sadece akran koçluğu ile ilişkili olduğu söylenemez. Öğrencilerin diğer derslerden elde ettikleri birikim, süreç içinde olgunlaşma gibi kontrol edilemeyen değişkenlerin sonucu ne kadar etkilediği bilinememektedir. Sonraki araştırmalarda öğretmen adaylarını öğretim öz yeterliklerinin ön ve son testlerle belirlenmesi önerilebilir.

Etik Kurul İzin Bilgisi Bu araştırma, Bartın Üniversitesi Sosyal ve Beşeri Bilimler Etik Kurulunun 12/05/2020 tarihli ve 14 sayll karart ile alınan izinle yürütülmüşstür. 


\section{Kaynakça / References}

Alsaleh, A., Alabdulhadib, M., \& Alrwaishedb, N. (2017). Impact of peer coaching strategy on pre-service teachers' professional development growth in Kuwait. International Journal of Educational Research, 86(2017), 36-49. doi: 10.1016/j.ijer.2017.07.011

Anderson, N. A., Barksdale, M. A., \& Hite, C. E. (2005). Preservice teachers' observations of cooperating teachers and peers while participating in an early field experience. Teacher Education Quarterly, 32(4), 97-117.

Arslan Dönmez, S. (2020). Mesleki gelişsim temelli akran koçluğu uygulamasına ilişkin bir inceleme. (Yayımlanmamış yüksek lisans tezi). Alanya Alaaddin Keykubat Üniversitesi, Antalya.

Bal, M. (2018). Türkçe dersinin 21. yüzyıl becerileri açısından incelenmesi. Turkish Studies, 13(4), 49-64. doi:10.7827/TurkishStudies. 12922

Bayındır, N., Çavdar, H. ve Gökçe, M. (2016). Öğretmen adaylarının ideal öğretimsel becerilere ilişkin beklentileri. Uşak Üniversitesi Sosyal Bilimler Dergisi, 9(1), 79-88.

Bowman, C. L., \& McCormick, S. (2000). Comparison of peer coaching versus traditional supervision effects. The Journal of Educational Research, 93(4), 256-261. doi: 10.1080/00220670009598714

Britton, L. R., \& Anderson, K. A. (2010). Peer coaching and preservice teachers: Examining an underutilized concept. Teaching and Teacher Education, 26(2), 306-314. doi: 10.1016/j.tate.2009.03.008

Büyüköztürk, Ş. (2011). Sosyal bilimler için veri analizi el kitabı (14. baskı). Ankara: Pegem Akademi.

Creswell, J. W., \& Plano Clark, V. L. (2015). Karma yöntem araştırmaları tasarımı ve yürütülmesi. (B. Dede ve S. B. Demir, çev.). Ankara: Anı Yayıncılık.

Çapan, S. A. ve Bedir, H. (2019). Pre-service teachers' perceptions of practicum through reciprocal peer mentoring and traditional mentoring. Journal of Language and Linguistic Studies, 15(3), 953-971. doi:10.17263/j1ls.631539

Demirel, F. (2013). Akran ĕgitiminin matematik dersinde kullanımının öğrenci tutumu, başarısı ve bilgi kalıcılı̆̆ına etkisi. (Yayımlanmamış yüksek lisans tezi). Erciyes Üniversitesi, Kayseri.

Göker, S. D. (2006). Impact of peer coaching on self-efficacy and instructional skills in TEFL teacher education. System, 34(2), 239-254. doi: 10.1016/j.system.2005.12.002

Hooker, T. (2013). Peer coaching: A review of the literature. Waikato Journal of Education, 18(2), 129-139. doi:10.15663/wje.v18i2.166

Huston, T., \& Weaver, C. L. (2008). Peer coaching: Professional development for experienced faculty. Innovations in Higher Education, 33, 5-20. doi: 10.1007/s10755-007-9061-9.

Johnson, R. B., \& Cristensen, L. (2014). Educational research quantitative, qualitative and mixed approaches. (5th ed.). California: SAGE Publications, Inc.

Karakaya Cirit, D. ve Aydemir, S. (2019). Akran koçluk uygulamasının fen bilgisi öğretmen adaylarının teknolojik pedagojik alan bilgisine etkisi. Inönü Üniversitesi Eğitim Fakültesi Dergisi, 20(3), 933-951. doi:10.17679/inuefd.566462

Kasapoğlu, A. E. (2002). A suggested peer observation model as a means of professional development. (Yayımlanmamış yüksek lisans tezi). Bilkent Üniversitesi, Ankara.

Kavanoz, H. S. ve Yüksel, G. (2010). An investigation of peer teaching technique in student teacher development. The International Journal of Research in Teacher Education, 1(Special Issue), 1-19.

Koç, A. (2020). Bulut tabanlı akran ögretiminin öğretmen adaylarının akademik başarı, iletişim becerileri ve derse ilişkin tutumlarına etkisi. (Yayımlanmamış doktora tezi). İnönü Üniversitesi, Malatya.

Kurtts, S. A., \& Levin, B. B. (2000). Using peer coaching with preservice teachers to develop reflective practice and collegial support. Teaching Education, 11(3), 297-310.

Kuru Gönen, İ. (2016). A study on reflective reciprocal peer coaching for pre service teachers: Change in reflectivity. Journal of Education and Training Studies, (4)7, 221-235. doi: 10.11114/jets.v4i7.1452

Ladyshewsky, R. (2017). Peer coaching as a strategy to increase learning and development in organisational life A perspective. International Journal of Evidence Based Coaching and Mentoring, 15(1), 4-10. 
Lockwood, J. R., McCombs, J. S., \& Marsh, J. A. (2010). Linking reading coaches and student achievement: Evidence from Florida middle schools. Educational Evaluation and Policy Analysis, 32(3), 372-388. doi:10.3102/0162373710373388

Lu, H. (2010). Research on peer coaching in preservice teacher education - A review of literature. Teaching and Teacher Education, 26(2010), 748-753. doi: 10.1016/j.tate.2009.10.015

Miles, M. B., \& Huberman, A. M. (2019). Nitel veri analizi (3. baskı). (S. Akbaba Altun ve A. Ersoy, çev. ed.) Ankara: Pegem Akademi.

Mirzeoğlu, A. D. ve Özcan, G. (2015). Akran öğretimiyle işlenen okul deneyimi dersi hakkında öğrenci görüşleri ve kazanımları. Sport Sciences, 10(4), 16-33.

Müldür, M. ve Çevik, A. (2020). Türkçe eğitiminde ders imecesi modelinin uygulanmasına ilişkin nitel bir araştırma. Turkish Studies - Educational Sciences, 15(1), 303-324. doi: 10.29228/TurkishStudies.40484

Ovens, A. (2004). Using peer coaching and action research to structure the practicum: An analysis of student teacher perceptions. Journal of Physical Education New Zealand, 37(1), 45-60.

Özdemir, S. (2019). Türkçe ögretmeni adaylarının mikro öğretim uygulamalarında gözlenen planlama ve uygulama sorunları: Okuma eğitimi örneklemi. Sözel Bildiri, 12. Uluslararası Türkçenin Eğitimi-Öğretimi Kurultayı, İzmir.

Pierce, T., \& Miller, S. P. (1994). Using peer coaching in preservice practica. Teacher Education and Special Education, 17(4), 215-223.

Sağlam, Y. ve Kanadlı, S. (2021). Nitel veri analizinde kodlama (4. baskı). Ankara: Pegem Akademi.

Scott, V., \& Miner, C. (2008). Peer coaching: Implication for teaching and program improvement. Transformative Dialogues: Teaching and Learning Journal, 1(3), 1-11.

Starr, J. (2003). The coaching manual: The definitive guide to the process, principles and skills of personal coaching. Edinburg: Pearson.

Sullivan, P. B., Buckle, A., Nicky, G., \& Atkinson, S. H. (2012). Peer observaion of teaching as a faculty development tool. BMC Medical Education, 12(26), 1-6.

Vacilotto, S., \& Cumings, R. (2007). Peer teaching in TEFL/TESL programmes. ELT Journal, 61(2), 153-160.

Yalçın Arslan, F., \& İlin, G. (2013). Effects of peer coaching for the classroom management skills of teachers. Journal of Theory and Practice in Education, 9(1), 43-59.

Yıldırım, A. ve Şimşek, H. (2013). Sosyal bilimlerde nitel araştırma yöntemleri (9. baskı). Ankara: Seçkin Yayıncilık. 